\title{
Eduardo Casaroto
}

\section{MELHORANDO A UTILIZAÇÃO DA REAÇÃO DE AMPLIFICAÇÃO DE ÁCIDOS NUCLEICOS PARA A DETECÇÃO DE ENTEROVIRUS E HERPES SIMPLES VÍRUS TIPO I E II PARA PACIENTES COM SUSPEITA DE MENINGITE}

Dissertação apresentada à Sociedade Beneficente Israelita Brasileira Albert Einstein, para obtenção do Título de Mestre em Ciências da Saúde. 


\section{Eduardo Casaroto}

\section{MELHORANDO A UTILIZAÇÃO DA REAÇÃO DE AMPLIFICAÇÃO DE ÁCIDOS NUCLEICOS PARA A DETECÇÃO DE ENTEROVIRUS E HERPES SIMPLES VÍRUS TIPO I E II PARA PACIENTES COM SUSPEITA DE MENINGITE}

Dissertação apresentada à Sociedade Beneficente Israelita Brasileira Albert Einstein, para obtenção do Título de Mestre em Ciências da Saúde.

Orientador: Dr. Alexandre Rodrigues Marra

São Paulo

2015 


\section{Eduardo Casaroto}

Melhorando a utilização da reação de amplificação de ácidos nucleicos para a detecção de enterovirus e herpes simples vírus tipo I e II para pacientes com suspeita de meningite / Eduardo Casaroto. -São Paulo, 2015.

xii, $46 \mathrm{f}$.

Dissertação (Mestrado) - Sociedade Beneficente Israelita Brasileira Albert Einstein. Instituto Israelita de Ensino e Pesquisa Albert Einstein. Programa de Pós-Graduação em Ciências da Saúde.

Título em inglês: Improving the use of nucleic acid amplification test to detect enterovirus and herpes simplex virus I and II in patients with meningitis suspected.

1. Meningite. 2. Enterovirus. 3. Herpes simples. 4. Técnicas de amplificação de ácido nucleico. 5. Reação em cadeia da polimerase.

Elaborada pelo Sistema Einstein Integrado de Bibliotecas 
SOCIEDADE BENEFICENTE ISRAELITA BRASILEIRA ALBERT EINSTEIN

Coordenador do Curso de Pós-Graduação Prof. Dr. Luiz Vicente Rizzo 


\section{Eduardo Casaroto}

\section{MELHORANDO A UTILIZAÇÃO DA REAÇÃO DE AMPLIFICAÇÃO DE ÁCIDOS NUCLEICOS PARA A DETECÇÃO DE ENTEROVIRUS E HERPES SIMPLES VÍRUS TIPO I E II PARA PACIENTES COM SUSPEITA DE MENINGITE}

Presidente da banca: Dr. Alexandre Rodrigues Marra

BANCA EXAMINADORA

Membros titulares:

Prof. Dr. Guilherme Henrique Campos Furtado

Profa. Dra. Marinês Dalla Valle Martino

Membros suplentes:

Prof. Dr. Fábio Rodrigues Kerbauy

Prof. Dr. Thiago Domingos Corrêa

Aprovada em: 26/11/2015. 


\section{Dedicatória}

Ao Dr. Alexandre Rodrigues Marra, orientador dessa tese, por todo empenho que demonstrou a cada passo dado rumo à conclusão desse projeto, pelo exemplo de dedicação e perseverança, pela humildade que é uma de suas características mais nobres e marcantes, pela sabedoria em como conduzir e incentivar seus alunos e por tantas outras qualidades que não consigo expressar, mas que são responsáveis pela minha imensa gratidão a tudo o que fez e tem feito pela minha pessoa, pelo meu crescimento e pelo meu sucesso. 


\section{Agradecimentos}

À Deus, por ter me concedido a oportunidade de exercer a Medicina, de ganhar conhecimento a cada dia, de fazer novas e belas amizades, de conhecer e desbravar tantos lugares abençoados ao redor desse mundo em função da Medicina.

Aos meus pais, que concederam todo o suporte e apoio necessário em todos os dias da minha vida, fonte de inesgotável amor e confiança, meus sinceros agradecimentos.

Aos meus irmãos, que sempre cuidaram de mim com o maior zelo, que batalharam para que eu tivesse boas condições de estudo, e que foram essenciais para a conclusão desse sonho - o Mestrado.

À minha cara metade, que teve paciência durante esse período de grande envolvimento com a pós-graduação, sou muito grato por todos os bons e melhores sentimentos que tens por mim. Te amo!

Aos meus grandes amigos, irmãos escolhidos por mim, que sempre estiveram por perto nos melhores e piores momentos da minha vida, fonte de apoio incondicional, sou muito grato por tê-los em minha vida.

Aos meus colegas de turma da Residência, particularmente a Residência de Terapia Intensiva, que fizeram com que as dificuldades encontradas naquela caminhada fossem muito mais amenas do que poderiam ter sido, não fosse pelo seu companheirismo.

Aos médicos com quem tive contato ao longo de toda minha formação, sou grato a todos eles pelo dom da transmissão do conhecimento e por terem contribuído de maneira essencial para minha bagagem atual.

Ao Centro de Terapia Intensiva Adulto do Hospital Israelita Albert Einstein, que me acolhe desde 2009, que faz com que eu realmente me sinta confortável frente ao ambiente já tão familiar e aos inúmeros amigos que aqui tive a felicidade de conhecer.

Ao Departamento de Microbiologia e toda sua equipe, pela participação ativa na execução desse projeto, desde seu desenvolvimento, até a publicação do artigo e a Defesa da Tese, fornecendo todos os artifícios e ferramentas necessárias para que isso fosse possível. 
À banca examinadora do exame de qualificação, pela disponibilidade em participar desse momento tão importante, e pela generosidade das palavras com as quais fizeram suas considerações, correções e orientações.

À banca examinadora da defesa da tese, é uma honra tê-los junto a mim nesse momento tão especial. Meus sinceros agradecimentos pela pronta disponibilidade e pelo carinho que demonstraram gratuitamente.

Ao Programa de Pós-Graduação stricto sensu em Ciências da Saúde do Instituto Israelita de Ensino e Pesquisa Albert Einstein, à Secretaria Acadêmica e a todos os docentes envolvidos, é uma honra ser membro discente da primeira turma desse programa. Meu muito obrigado a todos vocês. 


\section{Sumário}

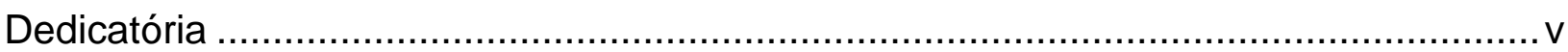

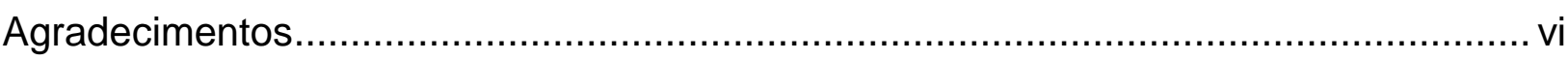

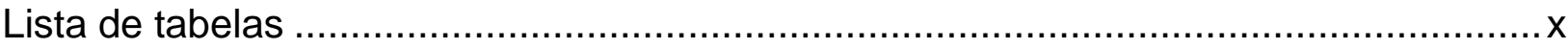

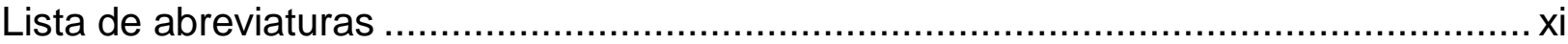

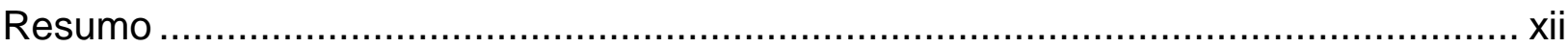

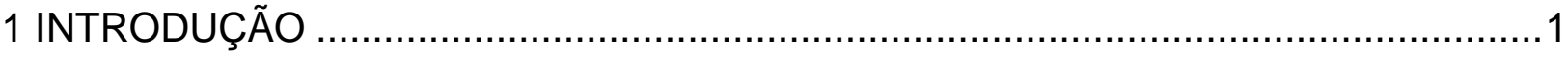

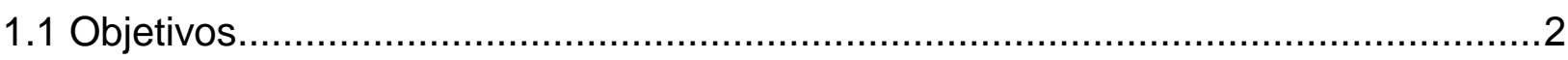

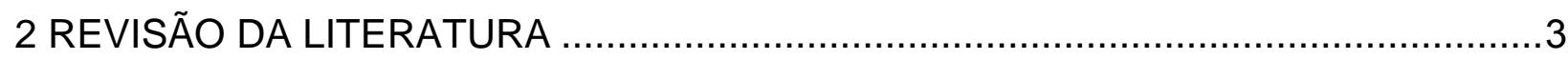

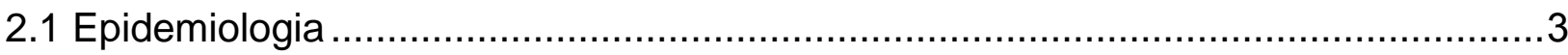

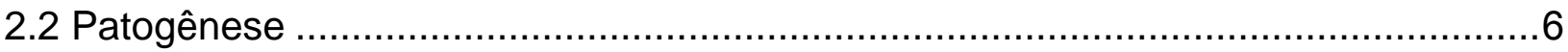

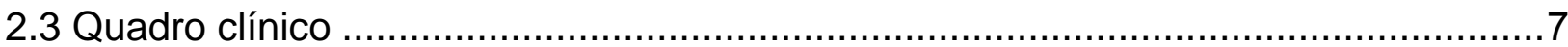

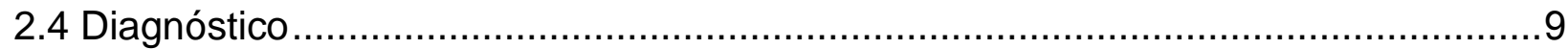

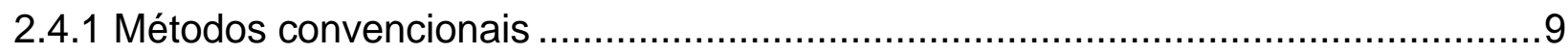

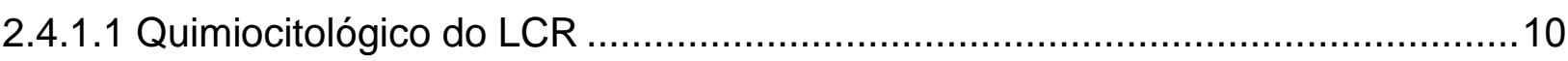

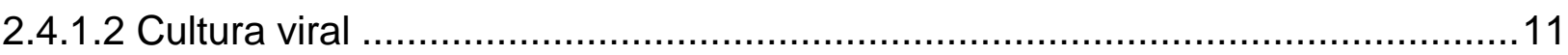

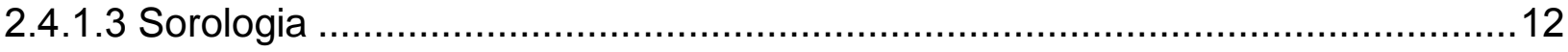

2.4.1.4 Imunohistoquímica.............................................................................. 12

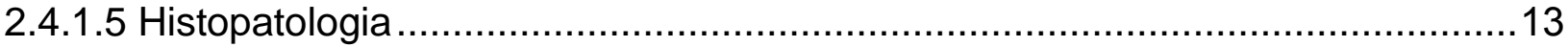

2.4.1.6 Proteína C-Reativa ................................................................................. 13

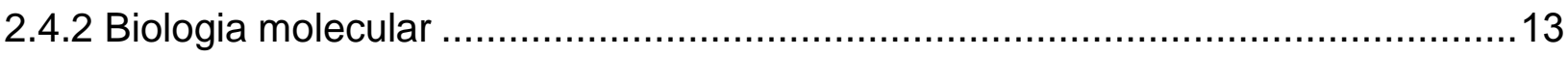

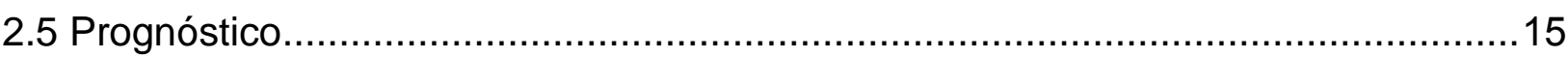

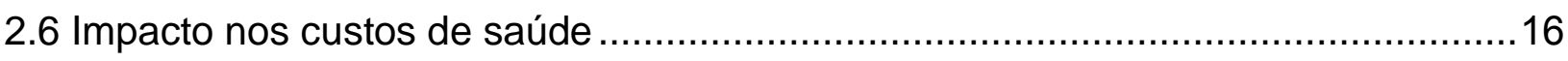

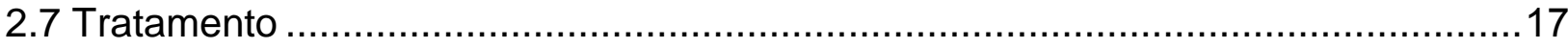

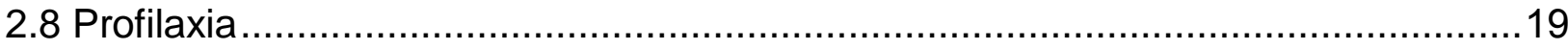

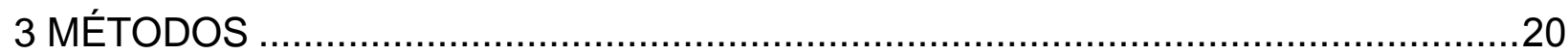

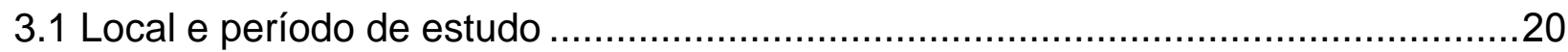

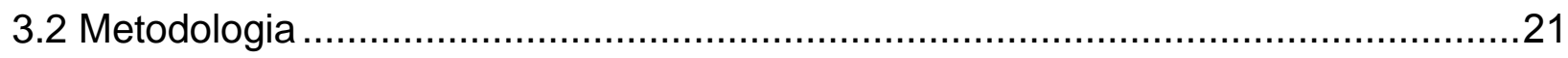

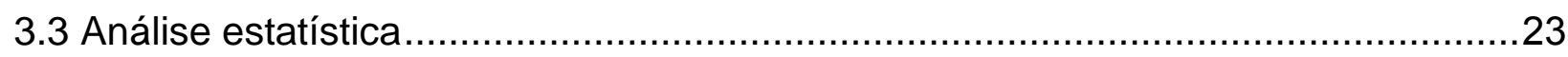

3.4 Isenção do Termo de Consentimento Livre e Esclarecido .................................23

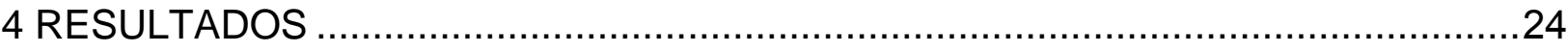

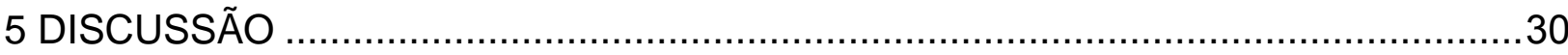

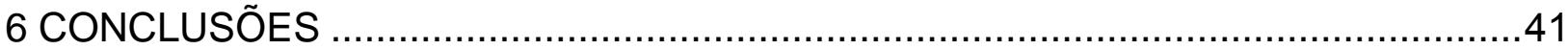


7 REFERÊNCIAS .

42

Abstract

Apêndice 


\section{Lista de tabelas}

Tabela 1. Classificação dos enterovirus humanos .............................................

Tabela 2. Etiologia da meningite asséptica ................................................... 5

Tabela 3. Síndromes clínicas e enterovirus associados .....................................8

Tabela 4. Manifestações Clínicas de infecções por enterovirus não-polio .....................9

Tabela 5. Características entre os diferentes métodos de amplificação do ácido nucleico para enterovirus utilizadas no Hospital Israelita Albert Einstein .....................22

Tabela 6. Resultados obtidos com o teste de amplificação de ácido nucleico .............24

Tabela 7. Dados demográficos, clínicos e liquóricos da amostra englobando pacientes com meningite por enterovirus e herpes simples vírus..........................................26

Tabela 8. Perfil das amostras de líquido cefalorraquidiano englobando enterovirus e

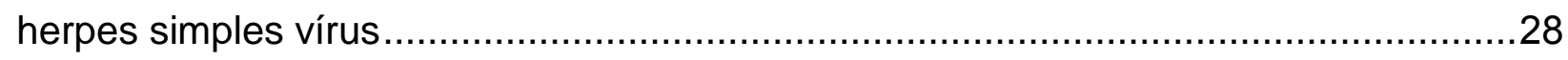

Tabela 9. Dados demográficos e clínicos referentes às meningites por enterovirus.....28

Tabela 10. Perfil das amostras de líquido cefalorraquidiano englobando as meningites por enterovirus. 29 


\section{Lista de abreviaturas}

dp Desvio padrão

EBV Vírus do Epstein-Baar

EV Enterovirus

(F) Teste exato de Fisher

GXEA GeneXpert Enterovirus Assay

HIAE Hospital Israelita Albert Einstein

HSV Herpes simples vírus

$\lg A \quad$ Imunoglobulina $A$

IgG Imunoglobulina $\mathrm{G}$

IgM Imunoglobulina M

IQR Intervalo interquartil

LCR Líquido cefalorraquidiano

NAAT Teste de amplificação de ácido nucleico

NASBA Amplificação de ácido nucleico baseado em sequência

PCR Reação em cadeia da polimerase

RNA Ácido ribonucleico

RT-PCR Reação em cadeia da polimerase em tempo real

SNC Sistema nervoso central

SPSS Statistical Package for the Social Sciences

TAT Test turnaround time

VZV Vírus do varicela zoster 


\section{Resumo}

Introdução: Enterovirus e herpes simples vírus são causas comuns de meningite linfocítica. Objetivos: $O$ objetivo desse estudo foi analisar o impacto no uso do teste molecular para enterovirus e herpes simples vírus I e II em todos os casos suspeitos de meningite viral. Métodos: No período entre 18 de novembro de 2008 a 17 de novembro de 2009, todos os pacientes admitidos com suspeita de meningite viral (com pleocitose) teve uma amostra do líquido cerebroespinhal testado utilizando-se um teste de amplificação de ácido nucleico. Os dados foram coletados durante este período definido como fase II (intervenção) - e entre 18 de novembro de 2007 a 17 de novembro de 2008 - definido como fase I (observacional), quando tais testes estavam disponíveis, porém não eram usados de maneira rotineira. Resultados: No total, 2.536 amostras de líquido cerebroespinhal foram analisadas, das quais 1.264 da fase I e 1.272 da fase II. Desse total, o teste de amplificação de ácido nucleico para enterovirus foi solicitado em 123 casos durante a fase I ( $9,7 \%$ da amostra total da fase I) e em 221 casos na fase II (17,4\% da amostra total da fase II). Desses, enterovirus foi confirmado em $35(28,5 \%, 35 / 123)$ pacientes durante a fase I e $71(32,1 \%, 71 / 221)$ pacientes durante a fase II $(p=0,107)$. A taxa de diagnóstico de meningite por herpes simples vírus I e II não sofreu diferença entre os grupos (13 pacientes, $6,5 \%$ na fase I e 13 pacientes, $4,7 \%$ na fase II) ( $p=1,0)$, dos 200 casos na fase I e 274 casos na fase II. Conclusões: $O$ número de casos diagnosticados com meningite por enterovirus aumentou durante o período do estudo, levando a acreditar que tal estratégia de realização do teste de amplificação de ácido nucleico para enterovirus em todas as amostras de liquido cerebroespinhal com pleocitose é justificável. 


\section{INTRODUÇÃo}

As meningites linfocitárias podem ter várias etiologias, sendo as infecções virais as mais comuns. As meningites linfomonocitárias virais têm como etiologia principal os enterovirus, responsáveis por $80 \%$ a $85 \%$ dos casos. Dentre os enterovirus, predominam as diferentes espécies de vírus coxsackie e echovirus, que infectam predominantemente adultos jovens e crianças. ${ }^{(1-5)}$

Outros vírus podem estar associados à meningite linfomonocitária como, por exemplo, o vírus da caxumba (Paramyxoviridae). Em adultos, mas com uma epidemiologia peculiar, ocorrendo em regiões determinadas e muitas vezes na forma de surtos epidêmicos, estão as arboviroses (Saint Louis encephalitis, vírus La Crosse, Jamestown Canyon e outros). ${ }^{(6)}$

De maior importância pela gravidade clínica e possibilidade de intervenção terapêutica são as meningites e meningoencefalites causadas pelo herpes simples I e II, embora sejam responsáveis por apenas $0,5 \%$ a $3 \%$ de todas as meningites linfomonocitárias, ${ }^{(1)}$ podendo representar $35 \%$ quando avaliamos apenas a população adulta. ${ }^{(5)}$

Para o diagnóstico etiológico das meningites virais, principalmente por enterovirus e por herpes vírus tipo I e II, a reação de amplificação de ácidos nucleicos - NAAT, em virtude da sua alta sensibilidade e curto período para liberação do resultado, tem sido o exame laboratorial de escolha para o diagnóstico rápido e capaz de definir a instituição de tratamento antiviral ou não. (1,4,7) $^{-1}$

O diagnóstico diferencial entre a meningite viral e a meningite bacteriana é de fundamental importância tendo em vista a alta letalidade e as sequelas associadas às meningites bacterianas agudas, devendo-se então instituir o tratamento antimicrobiano o mais precocemente possível. O tratamento antimicrobiano para uma meningite bacteriana pode variar de 7 a 21 dias. O controle liquórico pode acontecer na dependência da evolução do paciente ser satisfatória ou não. ${ }^{(8)}$

A realização do NAAT para enterovirus e para herpes vírus tipo I e II auxilia o médico na definição da condução do caso clínico, evitando o uso desnecessário de antibióticos endovenosos, novas punções liquóricas para os pacientes, eventos adversos que possam ocorrer durante a internação, bem como 
diminuir o tempo de hospitalização dos pacientes com meningites, quando existe a certeza de serem meningites virais e não meningites bacterianas. . $^{(1,7,9-11)}$

\subsection{Objetivos}

1. Utilizar testes moleculares NAAT para enterovirus e herpes vírus tipo I e II para todos os pacientes com suspeita de meningite viral atendidos no Hospital Israelita Albert Einstein;

2. Avaliar se a implementação dessa ferramenta diagnóstica na rotina laboratorial da instituição é capaz de contribuir no manejo clínico dos pacientes expostos;

3. Comparar esses dados com igual período prévio à implementação dessa rotina laboratorial, quando o serviço possuía tais métodos diagnósticos disponíveis, mas eram realizados somente quando houvesse solicitação médica. 


\section{REVISÃO DA LITERATURA}

\subsection{Epidemiologia}

Infecções por enterovirus são comuns em crianças e adultos, embora as crianças sejam mais suscetíveis à infecção, provavelmente devido à ausência de resposta imune específica e cruzada secundária às exposições repetidas. ${ }^{(1,12)}$ A maioria das infecções ocasionadas pelos enterovirus são benignas e cursam de maneira auto-limitada..$^{(4,13,14)}$ Conjuntivite, infecção alta e baixa das vias aéreas são alguns exemplos, mas quadros mais graves também podem ocorrer, como meningite asséptica, encefalite, encefalomielite, miocardite e sepse neonatal por enterovirus. $^{(1,3,7,13)}$

Os enterovirus pertencem à família Picornaviridae - são vírus pequenos, envelopados, constituídos de uma cápsula protéica em formato de icosaedro e um núcleo com uma fita simples de RNA. ${ }^{(2,13,15,16)}$ Os enterovirus englobam coxsackievirus dos grupos $\mathrm{A}$ e $\mathrm{B}$, echovirus, poliovirus, rinovirus, entre outros, conforme demonstrado pela tabela 1 , somando ao todo mais de 90 sorotipos que podem causar doenças em humanos segundo a "International Committee on Taxonomy of Virus Classifications". ${ }^{(1-3,13,16)}$ Alguns desses sorotipos estão mais associados à meningite que outros, como Coxsackievirus B5, Echovirus tipo 4, 6, 9 e 30. ${ }^{(13)}$

Tabela 1. Classificação dos enterovirus humanos

\begin{tabular}{lc}
\hline \multicolumn{1}{c}{ Grupo } & Sorotipos \\
\hline Poliovirus & $1-3$ \\
Coxsackievirus grupo A & $1-22,24$ \\
Coxsackievirus grupo B & $1-6$ \\
Echovirus & $1-9,11-27,29-33$ \\
Enterovirus & $68-72^{*}$ \\
\hline * Vírus da hepatite A classificado previamente como Enterovirus \\
72, atualmente foi reclassificado como Heparnavirus. \\
Fonte: Traduzido de Zaoutis T, Klein JD. Enterovirus infections. \\
Pediatr Rev. 1998;19(6):183-91.(2)
\end{tabular}


Os enterovirus englobam os poliovirus, que particularmente representam uma preocupação para saúde pública. Os poliovirus foram erradicados de grande parte do mundo, mas algumas regiões como a África sub-Sahariana, Paquistão, Afeganistão e Síria, tem registrado circulação dos mesmos, apesar de todos os esforços globais para sua erradicação. ${ }^{(16)}$

A identificação dos sorotipos específicos não tem grande impacto do ponto de vista clínico. A importância da identificação reside no fato de termos a capacidade diagnóstica e a possibilidade de avaliação terapêutica de novas drogas antivirais para cada um desses agentes. ${ }^{(1)}$

A via fecal-oral é a principal via de contaminação, mas a via oral-oral e respiratória também são possíveis. ${ }^{(2,16,17)}$ São fatores de risco conhecidos para infecção: falta de saneamento, baixa classe socioeconômica e habitação em conglomerados. ${ }^{(2,16)}$ Os enterovirus são relativamente resistentes a vários solventes e detergentes a temperatura ambiente, ${ }^{(16)}$ do mesmo modo como suportam o $\mathrm{pH}$ ácido gastrointestinal do humano, podendo sobreviver durante dias em temperatura ambiente, corroborando o modo de transmissão fecal-oral. ${ }^{(2)}$

A idade está fortemente associada à apresentação clínica: envolvimento neurológico é mais comum entre os 5-15 anos, infecções graves em neonatos e crianças até os 2 anos de idade, enquanto miocardite entre os 20-40 anos. $^{(16)}$ De modo geral, a doença parece predominar no sexo masculino, o que pode ser justificado por uma imunodeficiência relativa. ${ }^{(13)}$

O termo meningite asséptica se aplica a todas as meningites com culturas negativas para bactérias no LCR. ${ }^{(15)}$ Cerca de 80 a $90 \%$ dos casos de meningite asséptica em que um agente é identificado são causados por enterovirus..$^{(1,2,4,6,7,10,11,13,15)}$ Alguns sorotipos comportam-se de maneira endêmica, como Coxsackievirus A9, B3 e B4 e Enterovirus 71, enquanto outros de maneira epidêmica e relacionada a surtos, como o Coxsackievirus $5 .^{(13)}$ Quando analisamos a população adulta (>16 anos de idade), o enterovirus aparece em cerca de $40 \%$ dos casos de meningite asséptica, seguido pelo HSV-2 (17\%) e VZV (17\%), EBV (12\%), HSV-1 (7\%) e vírus da caxumba (7\%). ${ }^{(18)}$ O vírus Varicela-Zoster parece ser subestimado como causa de meningite asséptica e encefalite. ${ }^{(5)}$ Outros quadros infecciosos também podem se apresentar como meningite asséptica, como por exemplo, tuberculose, micoplasma, leptospirose e doença de Lyme, ${ }^{(15)}$ além de outras causas não infecciosas, como meningite asséptica relacionada a drogas, mais relatada 
entre a população adulta do que na pediátrica. ${ }^{(15)}$ A tabela 2 enumera diversas causas possíveis para a meningite asséptica.

A meningite causada pelo vírus da caxumba tem se tornado cada vez menos frequente desde que o uso da vacina contra caxumba se difundiu. ${ }^{(13)}$ Apesar disso, países como a Turquia ainda não tinham a vacina contra caxumba de uso rotineiro à época em que o estudo de Sensoy et al. foi realizado, e em sua amostra, foram diagnosticados 612 casos de meningite asséptica no período de Junho de 1999 a Dezembro de 2004, sendo que 310 (50,7\%) desses casos foram diagnosticados como meningite por caxumba. ${ }^{(13)}$

No Brasil, Santos et al. demonstraram que o Echovirus 30 foi 0 agente mais isolado de amostras de líquido cefalorraquidiano em pacientes com meningite viral, ${ }^{(17)}$ acompanhando os dados de uma série de outros estudos os quais demonstraram que o Echovirus 30 é um dos mais frequentes enterovirus causando surtos epidêmicos de meningite asséptica pelo mundo. ${ }^{(13)} \mathrm{O}$ mesmo agente também foi encontrado no estudo de Santos et al., também realizado no Brasil, tendo o Echovirus 30 como agente mais frequentemente isolado, tanto em casos esporádicos, como em surtos epidêmicos, sendo responsável pela hospitalização de várias crianças com meningite por tal agente. ${ }^{(17)}$

Tabela 2. Etiologia da meningite asséptica

\begin{tabular}{ll}
\hline Causas infecciosas & Causas não-infecciosas \\
\hline Vírus & Pós-infeccioso/pós-vacinal \\
Enterovirus - Coxsackie, ECHO & Rubéola \\
Vírus do grupo herpes & Varicela \\
HSV tipos I e II & Varíola \\
VZV & Vacina anti-rábica \\
CMV & Vacina anti-pertussis \\
EBV & Vacina anti-influenza \\
Vírus respiratórios & \\
Adenovírus & \\
Rinovírus & \\
Influenza tipos A e B & \\
Arbovirus & \\
Vírus da caxumba & \\
Vírus da Imunodeficiência Humana & \\
Bactérias & \\
Meningite parcialmente tratada & Anti-inflamatórios não-esteroidais \\
Infecção parameníngea & Sulfametoxazol-trimetoprim \\
\hline
\end{tabular}




\begin{tabular}{|c|c|}
\hline Endocardite & Amoxicilina \\
\hline Micoplasma pneumoniae & Azatioprina \\
\hline Mycobaterium tuberculosis & Imunoglobulina intravenosa \\
\hline Treponema pallidum & Isoniazida \\
\hline Leptospirose & Alopurinol \\
\hline $\begin{array}{l}\text { Fungos } \\
\text { Cryptococcus neoformans } \\
\text { Histoplasma capsulatum } \\
\text { Blastomyces dermatitides } \\
\text { Candida spp }\end{array}$ & $\begin{array}{l}\text { Doenças sistêmicas } \\
\text { Desordens do colágeno } \\
\text { Lupus Eritematoso Sistêmico } \\
\text { Granulomatose de Wegener } \\
\text { Vasculite no SNC } \\
\text { Artrite reumatóide } \\
\text { Doença de Kawasaki } \\
\text { Sarcoidose } \\
\text { Doença de Behcet }\end{array}$ \\
\hline $\begin{array}{l}\text { Parasitas } \\
\text { Toxoplasma gondii } \\
\text { Neurocisticercose } \\
\text { Bartonella henselae }\end{array}$ & $\begin{array}{l}\text { Doenças neoplásicas } \\
\text { Leucemia } \\
\text { Carcinomatose meníngea secundária a tumores } \\
\text { cerebrais }\end{array}$ \\
\hline $\begin{array}{l}\text { Rickettsiae spp } \\
\text { Febre das montanhas rochosas } \\
\text { Tifo }\end{array}$ & $\begin{array}{l}\text { Inflamação de estruturas vizinhas } \\
\text { Abscesso cerebral } \\
\text { Abscesso epidural }\end{array}$ \\
\hline
\end{tabular}

\subsection{Patogênese}

O período de incubação para a maioria das infecções por enterovirus varia de 3 a 10 dias. ${ }^{(2)}$ Os vírus acessam o hospedeiro por via oral ou respiratória, invadem o sistema respiratório superior ou o intestino delgado e ali se replicam, preferindo o tecido linfóide presente nessas regiões. ${ }^{(2,16)}$ De maneira geral, esses vírus podem infectar todos os tecidos do organismo, embora alguns apresentem tropismo por tecidos específicos, incluindo neurônios, cardiomiócitos e células epiteliais. ${ }^{(1,16)}$ A seguir, entram na corrente sanguínea gerando viremia, e disseminam para outros tecidos do organismo, incluindo sistema nervoso central, coração, fígado, pâncreas, adrenais, pele e membranas mucosas. ${ }^{(2)}$ Nesses sítios, os vírus continuam sua 
replicação, podendo resultar em uma viremia de maiores proporções, ${ }^{(2)}$ e permitindo portanto, que os enterovirus sejam detectados no sangue. A forma mais comum de infecção do SNC é através da viremia, com alguns sorotipos exibindo neurotropismo ou neurovirulência aumentados. ${ }^{(2)}$

A resposta imune dos enterovirus envolve um pico precoce de $\operatorname{lgM}$ em 7 a 10 dias, seguido por uma elevação da $\lg G$ e $\lg A$ intestinal. ${ }^{(2)}$ Existe uma relativa imunidade à reinfecção pelo mesmo sorotipo, mas caso ela ocorra, os sintomas são mais amenos e a doença pode ser subclínica. ${ }^{(2)}$ O sistema imune em desenvolvimento dos neonatos e crianças, bem como a ausência de anticorpos neutralizadores maternos parace estar associado à sua susceptibilidade aumentada às formas graves das doenças. ${ }^{(16)}$

Muitos dos vírus que causam meningite viral apresentam uma distribuição sazonal, predominando principalmente no verão e outono. ${ }^{(1,3,4,6,7,11,13,14)}$

O HSV encontra-se habitualmente em alguma região do tecido cerebral. O HSV-1 usualmente estabelece sua latência no gânglio trigêmio, estando mais relacionado à encefalite, enquanto o HSV-2 no gânglio sensorial sacral, estando mais relacionado à meningite. ${ }^{(18)} \mathrm{A}$ meningite por HSV-2 pode ocorrer como parte de uma infecção primária ou como resultado de reativação, e em casos de meningite recorrente, tentativas de se isolar o HSV no LCR não tiveram sucesso. ${ }^{(18,19)} \mathrm{O}$ HSV é transmitido por contato humano, e parece não ter distribuição sazonal. ${ }^{(14)} \mathrm{O}$ VZV estabelece sua latência em gânglios da coluna dorsal e sua reativação raramente é associada com meningite clínica. ${ }^{(18)}$

\subsection{Quadro clínico}

Os enterovirus têm a peculiaredade de poder causar uma grande diversidade de doenças, ${ }^{(1)}$ com diferentes graus de gravidade. Muitas das infecções ocasionadas pelos enterovirus são benignas, e podem se manifestar por um quadro febril, ou através de síndromes específicas, como a doença mão-pé-boca, herpangina, pleurodinia, miopericardite e poliomielite. ${ }^{(1,2)}$ Contudo, os enterovirus também são responsáveis por quadros infecciosos mais graves, como meningite, encefalite, miocardite, sepse neonatal e infecções em pacientes imunocomprometidos. ${ }^{(1)}$ Tais situações frequentemente requerem hospitalização, ampla investigação diagnóstica e 
mesmo terapia antimicrobiana empírica, quando não for possível descartar infecção bacteriana. ${ }^{(1)} \mathrm{A}$ tabela 3 demonstra as principais síndromes clínicas relacionadas aos enterovirus e os vírus predominantes em cada uma dessas síndromes.

Dentre as doenças graves, destaca-se a meningite por enterovirus. A apresentação clínica é bastante dependente da faixa etária acometida e inclui cefaléia, febre, irritabilidade, rigidez de nuca, fotofobia, náusea e vômito. ${ }^{(1-3,11,13,17)} \mathrm{A}$ forma mais comum de apresentação é criança jovem com febre e irritabilidade, e em crianças mais velhas, febre e cefaléia. Rigidez de nuca se encontra presente em até $50-70 \%$ dos pacientes. ${ }^{(1,2)}$ Dentre as crianças mais velhas, até um terço delas pode apresentar sinal de Kernig ou Brudzinski positivos. ${ }^{(2)} \mathrm{Na}$ faixa neonatal, geralmente ocorre febre, irritabilidade e outros achados inespecíficos, e frequentemente, envolvimento multiorgânico. ${ }^{(1,2)}$ Não é incomum observarmos o padrão bifásico da doença, com sinais de comprometimento do SNC somados à recorrência da febre..$^{(2)}$

Tabela 3. Síndromes clínicas e enterovirus associados

\begin{tabular}{|c|c|c|}
\hline Síndrome & Vírus predominante & Achados clínicos \\
\hline $\begin{array}{l}\text { Doença febril } \\
\text { não-específica }\end{array}$ & Todos os tipos & $\begin{array}{c}\text { Doença febril (ocasionalmente bifásica), com } \\
\text { sintomas inespecíficos de trato respiratório e } \\
\text { gastro-intestinal }\end{array}$ \\
\hline $\begin{array}{l}\text { Meningite } \\
\text { asséptica }\end{array}$ & $\begin{array}{l}\text { Echovirus e } \\
\text { Coxsackievirus grupo B }\end{array}$ & $\begin{array}{c}\text { Febre, sinais meníngeos, leve pleocitose ao LCR, } \\
\text { glicorraquia e proteinorraquia habitualmente } \\
\text { normal, ausência de bactéria }\end{array}$ \\
\hline Herpangina & Coxsackievirus grupo A & $\begin{array}{l}\text { Febre, vesículas orais dolorosas em tonsilas e } \\
\text { faringe posterior }\end{array}$ \\
\hline $\begin{array}{l}\text { Doença mão-pé- } \\
\text { boca }\end{array}$ & Coxsackievirus A16 & $\begin{array}{l}\text { Febre, vesículas em mucosa oral e língua, } \\
\text { superfícies interdigitais das mãos e dos pés }\end{array}$ \\
\hline $\begin{array}{l}\text { Exantema não- } \\
\text { específico }\end{array}$ & Echovirus & Rash de padrão variável, com ou sem febre \\
\hline Pleurodinia & Coxsackievirus B3 e B5 & $\begin{array}{c}\text { Incomum, epidêmico, febre, mialgia intensa em } \\
\text { tórax e abdome }\end{array}$ \\
\hline Miocardite & Coxsackievirus grupo B & $\begin{array}{l}\text { Incomum, miocardite/pericardite, pode se } \\
\text { apresentar com insuficiência ou arritmias cardíacas }\end{array}$ \\
\hline $\begin{array}{l}\text { Conjuntivite } \\
\text { hemorrágica } \\
\text { aguda }\end{array}$ & Enterovirus 70 & $\begin{array}{l}\text { Causa epidêmica de conjuntivite, com hemorragia } \\
\text { subconjuntival, edema palpebral, dor ocular, sem } \\
\text { sintomas sistêmicos }\end{array}$ \\
\hline Doença neonatal & $\begin{array}{l}\text { Coxsackievirus grupo B e } \\
\text { echovirus }\end{array}$ & Meningoencefalite, hepatite, miocardite \\
\hline
\end{tabular}

Fonte: Traduzido de Zaoutis T, Klein JD. Enterovirus infections. Pediatr Rev. 1998;19(6):183-91. ${ }^{(2)}$

A tabela 4 lista os principais sinais e sintomas apresentados nas infecções por enterovirus não-polio. 
Tabela 4. Manifestações Clínicas de infecções por enterovirus não-polio

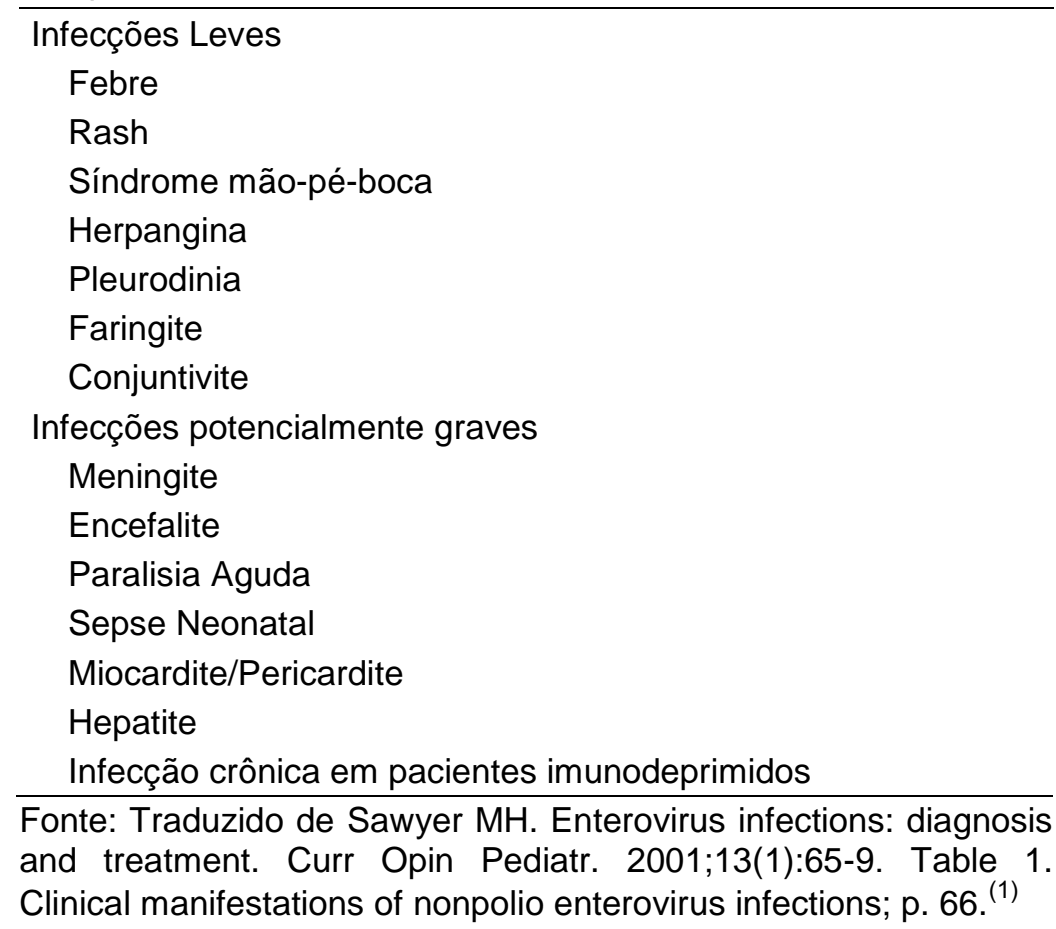

Anormalidades neurológicas específicas são raras e auxiliam na diferenciação entre meningite e encefalite ou mielite. ${ }^{(1)} \mathrm{Na}$ meningite, pode haver persistência da cefaléia por meses, necessitando tratamento com amitriptilina e antiinflamatórios hormonais. ${ }^{(14)}$ Quando ocorre encefalite, essa é geralmente global, o que pode ajudar a diferenciar da apresentação focal observada frequentemente na encefalite pelo $\mathrm{HSV}^{(2)}$ A encefalite pelo enterovirus é grave e, ao contrário da meningite, pode resultar em sequelas a longo prazo. ${ }^{(2)}$

A duração da meningite viral é comumente inferior a 7 dias entre as crianças, podendo se estender por semanas em adolescentes e adultos. ${ }^{(1)}$

\subsection{Diagnóstico}

\subsubsection{Métodos convencionais}

As infecções por enterovirus são frequentemente diagnosticadas clinicamente sem a identificação do tipo de vírus envolvido, contudo, em certas condições clínicas como ocorre na meningite, por exemplo, a identificação é recomendada. ${ }^{(2)}$ Os métodos mais comumente utilizados para diagnóstico envolvem a 
análise do líquido cefalorraquidiano, cultura, sorologia e amplificação de ácido nucleico. ${ }^{(1,3)}$ A confirmação diagnóstica é importante para a redução do tempo de hospitalização e utilização de antibiótico ${ }^{(1,20)}$ sendo um dentre tantos outros motivos que reintera a importância do diagnóstico das meningites virais utilizando métodos de biologia molecular.

\subsubsection{Quimiocitológico do LCR}

Nas meninigites virais a análise do LCR geralmente revela pleocitose de predomínio monomorfonuclear, comumente entre 100 a 300 leucócitos $/ \mathrm{mm}^{3}$, proteína normal ou discretamente elevada, glicorraquia normal e uma pressão de abertura normal ou levemente aumentada, ${ }^{(1,2,18)}$ sendo que entre as crianças o diagnóstico de meningite por enterovirus frequentemente ocorre na ausência de pleocitose ou aumento nos níveis de proteína. ${ }^{(1,2,9,20)}$ Entretanto, nas fases mais precoces da doença pode apresentar até 1.000 leucócitos $/ \mathrm{mm}^{3}$ e predomínio polimorfonuclear, dificultando ainda mais o diagnóstico. ${ }^{(1,2,7,10)}$ Conforme o agente viral envolvido pode haver uma diferenciação no padrão liquórico. ${ }^{(18)}$

Graham et al. demonstraram que mais da metade dos pacientes com pleocitose ao LCR tinham um padrão polimorfonuclear, apesar da etiologia viral confirmada. ${ }^{(20)}$ Como a meningite bacteriana apresenta uma granulocitose persistente no LCR, a utilização da punção lombar sequencial pode ser útil para diferenciar a etiologia viral da bacteriana. ${ }^{(2)}$ Tem sido descrito que a progressão dos leucócitos no LCR de polimorfonucleares para linfomononucleares pode durar as primeiras $48 \mathrm{~h}$ da infecção no SNC. ${ }^{(18)}$

Pacientes com infecção por HSV-2 ou VZV apresentam níveis de proteína no LCR significativamente maiores quando comparado com infecções pelo enterovirus $^{(18)}$ e aqueles infectados pelo HSV-2 apresentam níveis de leucócitos no LCR também mais elevados do que aqueles infectados pelo enterovirus. ${ }^{(18)}$ Estudos apontam que o nível de proteína no LCR não é sensível nem específico quando utilizado isoladamente ou mesmo quando utilizado associado à pleocitose. ${ }^{(12)}$

O diagnóstico diferencial para meningite asséptica é extremamente amplo e inclui doenças como febre das montanhas rochosas, doença de Lyme e arboviroses, que também são predominantes nas estações do verão e outono. ${ }^{(2)}$ 


\subsubsection{Cultura viral}

A cultura viral é considerada o método mais tradicional ${ }^{(9)}$ e foi tida como o padrão ouro durante muito tempo. ${ }^{(2)}$ Apresenta como vantagem a capacidade de isolar uma grande variedade de vírus, incluindo adenovirus, citomegalovírus (CMV), vários vírus do grupo dos enterovirus, HSV, influenza A e B, VZV, entre outros. ${ }^{(21)}$ Contudo, os enterovirus levam de 4 a 8 dias para crescer em ambiente de cultura celular, e desse modo, dificilmente contribuem no manejo do doente nos dias atuais, ${ }^{(1,9,11)}$ de tal maneira que não mais se recomenda seu uso, sendo esta eliminada da rotina prática laboratorial. ${ }^{(22)}$ Além disso, tem baixa sensibilidade $(<75 \%$ para 0 diagnóstico de meningite por enterovirus, sendo ao redor de 51\% para a cultura celular de rotina), crescimento pobre por alguns sorotipos de enterovirus e ainda requer uma equipe altamente qualificada para sua realização, fatores que em conjunto acabam elevando os custos do método..$^{(1,4,7,9,11,21)}$ Apesar do exposto, alguns médicos ainda solicitam cultura viral a despeito do uso do método de biologia molecular, talvez na esperança de se isolar algum sorotipo que não seja identificável pelo PCR. ${ }^{(22)}$ Os vírus podem ser isolados a partir das fezes, orofaringe, LCR e sangue, embora esse último não seja um sítio comum, visto que a viremia geralmente é indetectável no momento do surgimento dos sintomas. ${ }^{(2)}$ Muitos pacientes com meningite por enterovirus são hospitalizados e tratados com antibióticos parenterais até que haja melhora clínica e as culturas sejam negativas após $48 \mathrm{~h}$ de incubação, ${ }^{(7)}$ o que também contribui para 0 aumento nos custos de saúde associado aos cuidados desses pacientes.

Não há uma única linhagem celular capaz de permitir o crescimento de todas as diferentes cepas de enterovirus. ${ }^{(21)}$ Alguns vírus coxsackie do grupo $A$ também não crescem nas culturas, podendo ser uma razão da não identificação desse agente etiológico em uma série de casos. ${ }^{(13)}$ Outros vírus comumente relacionados às infecções do SNC, como HSV, VZV e CMV são pouco recuperados em cultura viral e necessitam de métodos alternativos de investigação, como sorologia e NAAT. ${ }^{(22)}$

Conforme sugerido em seu estudo, em situações onde os resultados do NAAT não puderem ser obtidos rapidamente, a inoculação das culturas celulares especialmente métodos mais ágeis, como o Super E-Mix, o qual fornece resultados em 24-48h - pode fornecer um resultado positivo antes que o resultado do NAAT esteja disponível. ${ }^{(21)}$ Contudo, o envio de rotina de amostras de LCR para cultura viral, 
especialmente para recuperar vírus não detectados pelo NAAT é dispendioso e oferece um benefício mínimo adicional, se houver, devendo realmente ser uma prática eliminada da rotina laboratorial habitual. ${ }^{(22)}$

\subsubsection{Sorologia}

Métodos sorológicos são usualmente utilizados para confirmar infecção durante surtos causados por um único sorotipo de enterovirus. ${ }^{(1)}$ É necessário um aumento de 4 vezes ou mais nos títulos de anticorpos entre o quadro agudo e a convalescença, ${ }^{(2)}$ sendo um método lento e necessitando coleta na fase aguda e na fase de convalescença da doença. ${ }^{(1,16)}$ Interpretação quantitativa de uma amostra sérica única não é útil visto que há uma grande variação entre os títulos para diferentes sorotipos em indivíduos saudáveis. Os mais de 60 sorotipos antigenicamente diferentes que não têm antígenos comuns tornam as técnicas sorológicas pouco práticas. ${ }^{(2)}$

A alta prevalência de EV e a reatividade cruzada limita sua utilidade clínica e epidemiológica. ${ }^{(16)}$

\subsubsection{Imunohistoquímica}

Apesar de ser um método pouco lembrado para o diagnóstico de EV, a imunohistoquímica tem a vantagem de identificar os antígenos virais e sua localização dentro dos tecidos. Uma série de anticorpos contra EV estão disponíveis para comercialização. A maior falha do anticorpo é que ocorre prova cruzada com uma grande variedade de outros vírus, prejudicando sua acurácia diagnóstica. Frequentemente resulta negativo em pacientes imunocompetentes sob um curso arrastado da doença. ${ }^{(16)}$

Assim, diante de sua não-especificidade, o método de PCR continua sendo necessário para o diagnóstico definitivo. ${ }^{(16)}$ 


\subsubsection{Histopatologia}

Os achados da histopatologia na meningite asséptica incluem leptomeningite, edema em grau variável e infiltrado linfohistiocitário. Podem estar presentes neutrófilos no parênquima e linfócitos perivascular. Nos casos de encefalite ou encefalomielite, gliose, nódulos na micróglia, infiltrados neutrofílicos e necrose podem ser encontrados. ${ }^{(16)}$

\subsubsection{Proteína C-Reativa}

A medida da Proteína C-Reativa também pode contribuir na diferenciação entre infecção viral e bacteriana, de tal modo que na infecção viral os níveis de proteína C-reativa raramente excedem $50 \mathrm{mg} / \mathrm{dL} .{ }^{(18)}$

\subsubsection{Biologia molecular}

Enquanto isso, técnicas de amplificação do ácido nucleico permitem o rápido diagnóstico de infecções por enterovirus, ${ }^{(1,7,9,18)}$ consistindo no melhor método diagnóstico disponível no momento..$^{(7,10,12,22)}$ O desenvolvimento do PCR tem contribuído para o aperfeiçoamento no diagnóstico de infecções virais do SNC, particularmente as causadas pelos enterovirus e HSV. ${ }^{(5,22)}$ Estudos que datam mais de 20 anos já demonstravam os primeiros achados positivos em relação à utilização da biologia molecular, inferindo inclusive a melhora no manejo dos pacientes com meningite asséptica. ${ }^{(23-25)}$ Previamente ao advento do PCR, o diagnóstico das infecções virais em SNC dependiam do isolamento do vírus no LCR ou em biópsia de tecido cerebral ou ainda da demonstração de anticorpo intratecal específico. ${ }^{(26)}$ Atualmente existem diferentes kits comerciais com sondas patógeno-específicas capazes de identificar cada microorganismo como uma espécie, que requerem pequeno volume de material, apresentam sensibilidade superior à da cultura viral $\mathrm{e}$ especificidade de $100 \%,{ }^{(1,2,4,22,27)}$ e o custo para sua realização semelhante ao da cultura viral. ${ }^{(7)}$ Uma parte dessa redução proporcional do custo se deve ao diagnóstico precoce. ${ }^{(4)}$ 
Com um tempo de positividade do método bem inferior ao da cultura viral, o NAAT permite redução em hospitalização desnecessária, bem como em intervenções diagnósticas e terapêuticas, principalmente em casos confirmados como meningite por enterovirus. ${ }^{(1,4,7,10,11)}$ Robinson et al. constataram uma redução estatisticamente significativa no uso de antimicrobiano e nos custos hospitalares dentre os pacientes que tiveram resultados positivos de PCR para enterovirus e comunicados à equipe médica em menos de 24 horas. ${ }^{(9)}$ Se a suspeita diagnóstica de meningite por enterovirus for confirmada pelo PCR e esse resultado for compatível com a condição clínica do paciente, então pode não ser mais necessário hospitalizar pacientes para aguardar resultados da cultura viral que pode levar mais de 48 horas. ${ }^{(9)}$ Ramers et al. demonstraram uma redução de quase 30 horas na permanência hospitalar, menos tempo em unidade de cuidados intermediários, além de redução em outros critérios também avaliados. ${ }^{(4)}$ Porém, para que esse benefício seja possível, é necessário que o serviço disponha de um adequado sistema de execução e análise do PCR, fornecendo resultados rapidamente. ${ }^{(4)}$

Contudo, em muitos centros, o exame de PCR não está disponível durante todos os dias da semana, a ponto de que pacientes admitidos durante a semana tiveram um dia a menos de internação e utilizaram menos antibióticos comparado àqueles admitidos no final de semana. ${ }^{(10)}$ No início do presente estudo, a análise biomolecular era realizada em apenas 3 dias da semana, ao custo aproximado de US\$175,00, e o resultado levava cerca de 24 horas para ser obtido. Em uma segunda fase, nosso serviço disponibilizava o PCR 6 dias por semana, no período entre 6:00 às 20:00, com alvo de liberação do resultado em cerca de 12 horas, ao custo aproximado de US\$85,00. Atualmente, o laboratório está capacitado para trabalhar 24 horas ao dia, todos os dias da semana, contribuindo para o uso mais corriqueiro dessa tecnologia, com um tempo para liberação dos resultados cada vez menor.

Estudos demonstram que nos casos onde o resultado do PCR para enterovirus encontrava-se disponível, houve uma redução de pelo menos 12 a 24 horas de hospitalização, o que também reduz significativamente os custos. Outros benefícios já reportados foram menor permanência em unidade de cuidado intermediário, número menor de solicitações de métodos de imagem como tomografia computadorizada e ressonância nuclear magnética, eletroencefalograma, além de terem recebido menos dias de antibióticos. ${ }^{(1,9,10)}$ Archimbaud et al. demonstraram a suspensão de antibióticos em $50-60 \%$ e aciclovir em $62 \%$ dos pacientes que tinham PCR positivo para 
enterovirus e HSV, respectivamente, a partir do momento em que se tinha o resultado disponível. ${ }^{(10)}$ Nossos dados não foram capazes de apontar esses mesmos resultados, contudo a amostra não foi estatisticamente significante. $O$ uso desnecessário de antibiótico, bem como o aumento nas taxas de resistência bacteriana são pontos que merecem atenção na abordagem da meningite por enterovirus. ${ }^{(1)} \mathrm{A}$ técnica do PCR para enterovirus pode ser mais valiosa em crianças jovens, nas quais as diferenças clínicas entre um quadro viral e bacteriano são mais sutis. ${ }^{(4)}$ É importante ressaltar que, embora raro, a co-infecção viral e bacteriana pode ocorrer, contudo nesses casos, espera-se um quadro clínico mais consistente com meningite bacteriana do que viral. ${ }^{(9)}$

Por se tratar de um exame altamente sensível, o método está sujeito a falso-positivos causados por contaminação no laboratório, reforçando a importância de um rigoroso controle de qualidade nos testes. ${ }^{(1)}$ Grande parte dos métodos de PCR inicialmente disponíveis foram realizados em duas etapas, ${ }^{(28)}$ e com o desenvolvimento tecnológico e científico, começaram a surgir métodos capazes de realizar a transcrição e a amplificação em um único passo, reduzindo o risco de contaminação. ${ }^{(29)}$ Liu et al. também demonstraram uma técnica de extração, amplificação e hibridização dos vírus de maneira simultânea, com simplicidade e especificidade, utilizando cerca de $100 \mu \mathrm{L}$ de amostra e fornecendo o resultado em $5,5 \mathrm{~h}$, reforçando sua adequação para detecção de HSV e EV através de uma única amostra de LCR. ${ }^{(27)}$

A habilidade para detectar e diferenciar rapidamente doenças associadas aos enterovirus daquelas associadas a outros vírus e/ou bactérias constitui num alvo essencial para fins terapêuticos, epidemiológicos e prognósticos, ${ }^{(17)}$ e desse modo, aliado às várias evidências disponíveis atualmente na literatura, o PCR para enterovirus deve ser realizado rotineiramente nos laboratórios hospitalares e ainda ser considerado como elemento do manejo inicial das meningites. ${ }^{(10,30)}$

\subsection{Prognóstico}

A meningite viral tem um prognóstico excelente quando comparado à encefalite e à encefalomielite pelo mesmo agente..$^{(1,16)}$ Embora essas duas últimas sejam menos frequentes, costumam se apresentar com maior gravidade, inclusive com sequelas a longo prazo podendo até mesmo ocasionar a morte. ${ }^{(16)}$ A duração da 
hospitalização habitualmente é mais curta nas infecções por enterovirus comparado com infecções por HSV-2 ou VZV. ${ }^{(18)}$

O EV71 é um dos principais EV associados a surtos epidêmicos, e as infecções por EV71 que cursam com acometimento do SNC tem uma probabilidade maior de sequela neurológica a longo prazo, além de atraso no desenvolvimento neurológico, como demonstrado por Chang et al. ${ }^{(31)}$ Esses danos são mais notáveis quanto mais grave a manifestação da doença e particularmente nas crianças abaixo dos 2 anos de idade. ${ }^{(31)}$

A meningite pelo HSV-2 tem um risco considerável de morbidade neurológica futura, e representa uma causa importante de meningite asséptica recorrente, ${ }^{(19)}$ enquanto a encefalite pelo HSV apresenta uma alta taxa de mortalidade, podendo chegar a $70 \%$ quando não tratada. ${ }^{(27)}$

\subsection{Impacto nos custos de saúde}

A meningite viral continua sendo uma causa importante de morbidade e encargos financeiros, e sem dúvida merece esforços para melhorias no diagnóstico, tratamento e profilaxia. ${ }^{(19)}$ Como já citado previamente, até $90 \%$ das meningites em que se isola um agente causal é motivada pelos enterovirus.

Como a meningite por enterovirus é um quadro usualmente benigno e auto-limitado, podemos imaginar que os custos de saúde envolvidos são pequenos. Contudo, na prática, sabemos que a maior parte desses pacientes, seja infantil ou adulto, encontram-se hospitalizados ${ }^{(1)}$ e os custos de saúde relacionados ao diagnóstico e aos cuidados dispensados às crianças com infecções por enterovirus são significativos. ${ }^{(7)}$ Vivenciamos uma era em que se faz essencial limitar o número de testes laboratoriais privilegiando o uso desses recursos guiados pelo quadro clínico do paciente, evitando a qualquer modo investigações que não sejam compatíveis com a situação clínica atual. ${ }^{(12)}$

É importante ainda lembrar que uma parcela desses pacientes estão recebendo antimicrobiano empiricamente, o que pode representar um problema em relação ao aumento nas taxas de resistência antimicrobiana, ${ }^{(1)}$ além dos riscos ao qual o paciente é exposto pelo simples fato de se encontrar hospitalizado. 
O diagnóstico precoce obtido com o NAAT pode melhorar o manejo e reduzir os custos dos cuidados das crianças com meningite pelo enterovirus, reduzindo tempo de internação hospitalar, despesas hospitalares e uso de antimicrobianos, como já demonstrado em diversos estudos prévios. ${ }^{(1,4,7,9-11)}$

\subsection{Tratamento}

Até pouco tempo não havia terapia específica disponível para tratamento das infecções por enterovirus, ${ }^{(1)}$ limitando-se ao tratamento sintomático e de suporte. ${ }^{(2,4)}$ Devido à ação dos anticorpos na fisiopatologia da doença, imunoglobulina intravenosa pode ser utilizada como parte da terapia nas infecções graves, em neonatos e em crianças imunodeprimidas. ${ }^{(1,2)}$

Uma droga que vem sendo estudada para tratamento da meningite viral, infecção respiratória e infecções no paciente imunodeprimido é o pleconaril. ${ }^{(1,6,14)}$ Os dados são limitados e sugerem redução na duração da cefaleia. ${ }^{(14)}$ Consiste em uma droga que inibe a replicação viral e ainda necessita estudos adicionais para avaliação de eficácia. ${ }^{(1)}$

Várias drogas se encontram em testes e elas podem ser agrupadas de acordo com seu principal mecanismo de ação. Assim sendo, os alvos terapêuticos em relação ao combate ao EV71 podem incluir: a) ligação do vírus à superfície celular e sua entrada (incluem nesse grupo o suramin sulfatado, heparan sulfato, NF449, kappa carrageenan, entre outros); b) capsídeo viral (pleconaril, pyridyl imidazolidinone); c) tradução do RNA viral (quinacrine, amantadine); d) processamento da poliproteína viral (rupintrivir, fisetin, rutin); e) membrana viral do complexo de replicação do RNA (DIDS, metrifudil, enviroxime, GW5074); f) complexo RNA-dependente e RNApolymerase (ribavirina). ${ }^{(32)}$ Uma outra droga em estudo é um derivado benzonitrila, chamado 4-[1-hydroxy-2-4,5-dimethoxy-2-nitrophenyl)ethyl]benzonitrile, também conhecido por LPCRW_0005. Essa droga demonstrou atividade antiviral contra os Rhinovirus, porém, o mesmo não aconteceu contra vários outros $E V$, incluindo Coxsackievirus B3, EV71 e poliovirus 1. ${ }^{(33)}$

A figura 1 demonstra uma representação esquemática com os sítios de atuação dos mais diferentes agentes antivirais em desenvolvimento. 


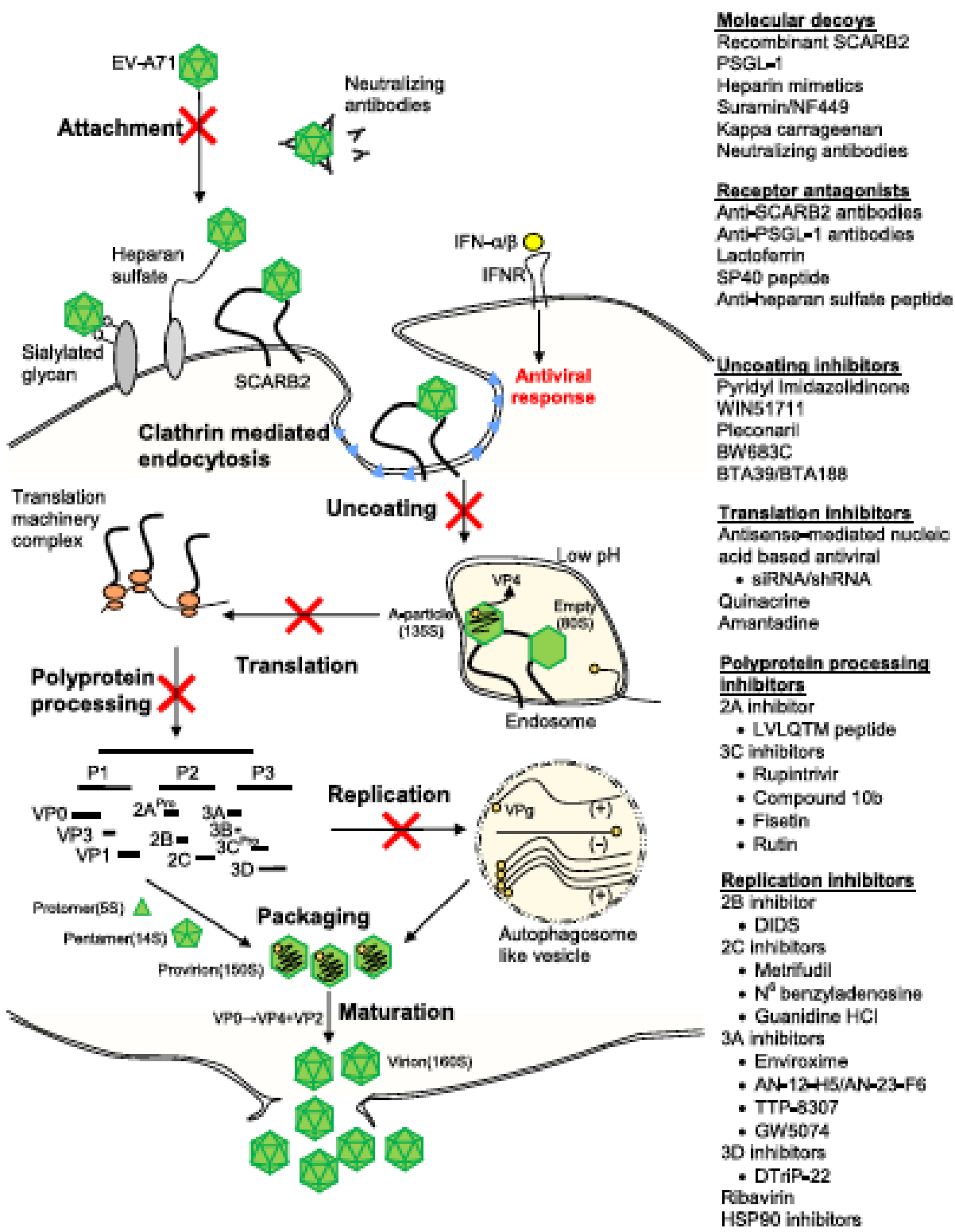

Fonte: Tan CW, Lai JK, Sam IC, Chan YF. Recent developments in antiviral agents against enterovirus 71 infection. J Biomed Sci. 2014 Feb 12;21(1):14. Figure 1 Schematic illustration of EV-71 intracellular infection and summary of the antiviral agents; p. $5 .^{(32)}$

Figura 1. Representação esquemática dos diferentes sítios de atuação dos agentes antivirais

No caso da infecção pelo HSV, especificamente a meningite pelo HSV-2, as informações corretas sobre tal diagnóstico quando confirmado, prognóstico e tratamento é possível e importante. ${ }^{(19)} \mathrm{O}$ aciclovir é considerado a droga de escolha para terapia precoce no tratamento de encefalite por HSV..$^{(14,18)}$

A disponibilidade de modelos animais adequados para teste dos antivirais pode acelerar o desenvolvimento dos mesmos, e esforços contínuos para profilaxia e tratamento são essenciais na ausência de uma vacina que seja eficaz. ${ }^{(32)}$ 


\subsection{Profilaxia}

O único enterovirus para o qual há vacina disponível é o poliovirus, cujo uso tem reduzido dramaticamente a incidência de poliomielite ao redor de todo o mundo. ${ }^{(2)}$

A profilaxia para meningite recorrente devido HSV-2 pode ser realizada eficazmente com aciclovir, valaciclovir ou famciclovir. ${ }^{(14)}$ 


\section{MÉTODOS}

\subsection{Local e período de estudo}

O estudo foi desenvolvido no Hospital Israelita Albert Einstein (HIAE) e nas unidades satélites nas quais havia serviço de Pronto-Atendimento, todos na cidade de São Paulo, no período entre 18 de novembro de 2008 a 17 de novembro de 2009. Para que fosse dado início ao estudo, foi instituída uma rotina de coleta de NAAT para enterovirus e herpes vírus I e II para todos os pacientes que tivessem suspeita de meningite viral, atendidos no pronto atendimento das unidades do HIAE. Os dados coletados neste período foram comparados aos dados do período de um ano anterior ao início da rotina institucional de coleta de NAAT para todas as suspeitas de meningite viral, ou seja, de 18 de novembro de 2007 a 17 de novembro de 2008. Desse modo, o estudo pode ser caracterizado como um estudo descritivo do tipo antes e depois.

Foram incluídos todos os pacientes que chegaram ao hospital com suspeita de meningite viral, independente da faixa etária. Foram excluídos da análise aqueles pacientes nos quais a celularidade e exames de bioquímica, tais como glicose, proteínas, cloreto e lactato, foram normais, constatando a ausência de meningite, e aqueles em que a bacterioscopia ou o látex foram positivos para meningite bacteriana.

Foi utilizada uma ficha onde constavam dados epidemiológicos (sexo, idade, hipótese diagnóstica, o número de punções liquóricas), dados clínicos (sinais e sintomas como presença de cefaléia, náusea e/ou vômito, rigidez de nuca, temperatura, fotofobia), uso prévio de medicamentos (corticosteróides, imunossupressores, antimicrobianos), dados laboratoriais (nível de hemoglobina e hematócrito, leucograma, número de plaquetas, sódio, potássio, creatinina, ureia, glicemia, fosfatase alcalina, proteína C reativa, análise do LCR, detecção de enterovirus e herpes vírus pelo método NAAT), e a data de alta hospitalar (Apêndice $1)$. 


\subsection{Metodologia}

Durante o período em que este trabalho foi realizado, nosso laboratório trabalhava com a única técnica de detecção de RNA de enterovirus que estava disponível no mercado nacional àquela época, que utilizava o sistema Nuclisens para amplificação específica do RNA viral pelo método Nucleic Acid Sequence Based Amplification (NASBA) e detecção por eletroquimioluminescência. ${ }^{(34)}$ A detecção de enterovirus e herpes simples vírus tipo I e II foi realizada com os kits Nuclisens EasyQ (Biomèrieux, Marcy- I'Etoile, França) específicos para estes patógenos, de acordo com as instruções do fabricante. Para cada paciente, foi coletado 1 mililitro de líquor. Os ácidos nucleicos foram extraídos com o equipamento EasyMag e posteriormente submetidos às reações de amplificação com os kits NucliSENS EasyQ® HSV 1 / 2 e NucliSENS EasyQ® Enterovirus. O kit para HSV 1 / 2 possui sondas marcadas com diferentes fluoróforos que identificam e diferenciam o HSV1 e HSV2. Já o kit para enterovirus possui sondas que detectam regiões conservadas entre os diferentes serotipos de enterovirus, incluindo poliovírus 1-3, coxsackievírus A2-12, A15-18, A20, A21, A24, coxsackievírus B1-6, echovírus 1-9, 11-15, 17-21, 24-27, 29-33 e Enterovirus 68-71. Quanto à sensibilidade do método, os coeficientes de exaustividade de $50 \% \mathrm{e}$ 95\% foram determinados como sendo 93 e 263 cópias por extraído de ácidos nucleicos, respectivamente. Ambos os kits possuem ainda uma sonda para detectar um controle interno, monitorando a qualidade do processo desde a etapa de extração. $A$ especificidade encontrada para o método foi de $100 \%$ e o nível de correlação com a cultura viral (do líquor, na nasofaringe e/ou de amostra retal) foi de $82,1 \%{ }^{(34)} \mathrm{O}$ método de extração resulta em ácidos nucleicos concentrados, altamente purificados, e com mínimas substâncias inibitórias, com um tempo de liberação do resultado de cerca de 6,5 horas. $^{(34)}$

Este sistema foi posteriormente substituído por outros kits com maior sensibilidade que propiciaram uma melhora importante na detecção de enterovirus em amostras de líquor: o kit ENTEROVIRUS Q-PCR Alert Kit (Nanogen Advanced Diagnostics S.p.A., C.so Torino, 89/d - 10090 Buttigliera Alta (TO) - ITALY) ${ }^{(35)}$ e no ano seguinte o kit Xpert EV (Cepheid, Sunnyvale, CA, USA), ${ }^{(36)}$ este último com tempo de liberação do resultado ainda menor, menor complexidade e pequena discrepância em 
relação aos agentes detectados quando comparado às outras duas técnicas. A tabela 5 enumera os três métodos utilizados e algumas de suas características.

Tabela 5. Características entre os diferentes métodos de amplificação do ácido nucleico para enterovirus utilizadas no Hospital Israelita Albert Einstein

\begin{tabular}{|c|c|c|c|}
\hline & NASBA & Nanogen & Cepheid \\
\hline $\begin{array}{l}\text { Nome do Kit } \\
\text { (Empresa) }\end{array}$ & $\begin{array}{c}\text { NucliSENS EasyQ® } \\
\text { Enterovirus (Biomérieux, } \\
\text { Boxtel, Holanda) }\end{array}$ & $\begin{array}{l}\text { ENTEROVIRUS Q- } \\
\text { PCR Alert Kit } \\
\text { (Nanogen, TO, Itália) }\end{array}$ & $\begin{array}{l}\text { Xpert EV (Cepheid, } \\
\text { CA, Estados Unidos) }\end{array}$ \\
\hline Período de uso & $01 / 2008-12 / 2010$ & $01 / 2011-02 / 2012$ & 03/2012 - atual \\
\hline Método & $\begin{array}{l}\text { Amplificação por } \\
\text { NASBA e tecnologia } \\
\text { molecular beacons }\end{array}$ & $\begin{array}{c}\text { Real Time PCR } \\
\text { (Taqman, MGB, } \\
\text { UNG) }\end{array}$ & $\begin{array}{c}\text { Real Time PCR } \\
\text { (cartucho fechado) }\end{array}$ \\
\hline Complexidade & Alta & Alta & Baixa \\
\hline $\begin{array}{l}\text { Tempo de } \\
\text { execução }\end{array}$ & 8 horas & 8 horas & 3 horas \\
\hline \multirow[t]{3}{*}{ Especificidade } & Poliovirus 1-3 & Poliovirus 1-3 & Poliovirus 1-3 \\
\hline & $\begin{array}{c}\text { Coxsackievírus A2-12, } \\
\text { A15-18, A20, 21, } 24 \\
\text { Coxsackievírus B1-6 }\end{array}$ & $\begin{array}{c}\text { Coxsackievírus A1-22 } \\
\text { e A24 } \\
\text { Coxsackievírus B1-6 }\end{array}$ & $\begin{array}{c}\text { Coxsackievírus A2-22 } \\
\text { e A24 } \\
\text { Coxsackievírus B1-6 }\end{array}$ \\
\hline & $\begin{array}{c}\text { Echovirus 1-9, 11-15, } \\
\text { 17-21, 24-27, 29-33 } \\
\text { Enterovirus } 68-71\end{array}$ & $\begin{array}{c}\text { Echovirus 1-9, 11-21, } \\
\text { 24-27, 29-33 } \\
\text { Enterovirus 68-71 }\end{array}$ & $\begin{array}{c}\text { Echovirus 1-7, 9, 11- } \\
21,24-27,29-33 \\
\text { Enterovirus 68-70 }\end{array}$ \\
\hline
\end{tabular}

O ensaio GeneXpert EV é projetado como um sistema integrado que une processamento das espécies, amplificação e detecção do RNA viral em tempo real em um cartucho descartável utilizando o aparelho GeneXpert Dx, levando cerca de 2,5h para a detecção do enterovirus no LCR. ${ }^{(7)}$ Esse ensaio é capaz de detectar RNA na região entre os nucleotídeos 452 e 596 do enterovirus ${ }^{(36)}$ e no primeiro ensaio multicêntrico publicado envolvendo essa técnica, foi observado uma sensibilidade de $97,1 \%$ e especificidade de $100 \%$. $^{(7)}$ Resultados semelhantes foram encontrados por Seme et al. em seu estudo, no qual foram avaliadas 162 amostras de LCR utilizando o então recentemente lançado GeneXpert, com outras duas metodologias que já eram utilizadas previamente naquele serviço, o PCR em tempo real e um kit denominado Argene, encontrando um elevado nível de concordância entre os métodos $(98,1 \%) .{ }^{(37)}$ Diante dos resultados obtidos ao longo de um ano de experiência com o novo método, aliado à sua completa automação e capacidade de diagnósticos rápidos, o GXEA pode ser considerado um ótimo teste na suspeita de meningite por enterovirus. ${ }^{(37)} A$ performance obtida com o ENTEROVIRUS R-gene ${ }^{\mathrm{TM}}$ (método de RT-PCR em tempo real) foi comparada àquela do GXEA. ${ }^{(38)}$ Hong et al. também compararam o GXEA com outro método de RT-PCR em tempo real, encontrando especificidade de $100 \%$ para ambos os métodos, com sensibilidade superior para o primeiro método. ${ }^{(39)}$ 
Marlowe et al. avaliaram 138 amostras de LCR comparando três metodologias: GeneXpert, TaqMan (PCR em tempo real) e NASBA. Os valores de sensibilidade e especificidade encontrados para os métodos foram respectivamente $100 \%$ e $100 \%$, 96\% e 100\%, e 87,5\% e 100\%. ${ }^{(30)}$ O coeficiente kappa entre Xpert e TaqMan foi de 1 , e entre o Xpert e NASBA foi de $0,89(p=0,85$ pelo teste de McNemar). ${ }^{(30)}$

Os testes de biologia molecular para pesquisa de HSV revelam resultados semelhantes àqueles obtidos para enterovirus. Atualmente há ensaios capazes de fazer a detecção do material genético de alguns vírus simultaneamente, como por exemplo, o HSV-1, HSV-2 e VZV, obtidos com o BD Max platform - técnica que extrai e amplifica o vírus em uma única etapa e disponibiliza o resultado em até 2 horas para uma série de espécies diferentes. ${ }^{(40)}$

\subsection{Análise estatística}

Variáveis contínuas foram comparadas através do teste $t$ de Student se apresentassem distribuição normal e do teste de Mann-Whitney caso não o fossem. As diferenças das proporções foram comparadas usando-se o teste Qui-Quadrado de Pearson ou o teste exato de Fisher quando apropriado. Os valores das médias foram reportados com \pm 1 desvio-padrão. $O$ valor de alfa foi definido como 0,05 e todos os testes com significância estatística foram considerados bicaudados. Todas as análises estatísticas foram desenvolvidas utilizando-se o programa "Statistical Package for the Social Sciences" (SPSS, Chicago, IL, USA, ver 11.5).

\subsection{Isenção do Termo de Consentimento Livre e Esclarecido}

O presente estudo foi aprovado pelo Comitê de Ética em Pesquisa do Hospital Israelita Albert Einstein. Tendo em vista que o NAAT é um exame realizado na rotina do hospital e sendo examinados apenas dados laboratoriais, e realizadas consultas a prontuários sem a exposição dos pacientes, não houve necessidade da aplicação de termo de consentimento. 


\section{RESULTADOS}

Ao todo foram realizadas 2.536 coletas de líquor no nosso serviço nesse período de 2 anos, sendo 1.264 no período pré-protocolo (fase I) e 1.272 no pósprotocolo (fase II). Esse número engloba 0 total de coletas realizadas, independentemente da suspeita clínica que tenha motivado a punção. Deste total de exames, foi solicitado NAAT para enterovirus em 123 casos $(9,7 \%$ da amostra da fase I) na fase I e em 221 casos (17,4\% da amostra da fase II) na fase II, e destes, 35 pacientes foram confirmados como meningite por enterovirus na fase I e 71 pacientes na fase II $(p=0,107)$. Em relação ao HSV I e II, foi solicitado NAAT em 200 casos na fase I e 274 casos na fase II, sendo confirmado o diagnóstico de meningite por HSV I e II em 13 pacientes na fase I e 13 pacientes na fase II, não havendo então diferença entre os dois grupos $(p=1,0)$ (Tabela 6 e Figura 2$)$.

Tabela 6. Resultados obtidos com o teste de amplificação de ácido nucleico

\begin{tabular}{lcccc}
\hline Variáveis & Fase I & Fase II & Total & Valor-p \\
\hline Líquor realizados no hospital & 1264 & 1272 & 2536 & NA \\
PCR solicitados para Enterovirus & 123 & 221 & 344 & NA \\
PCR solicitados para Herpes Vírus 1 e 2 & 200 & 274 & 474 & NA \\
Meningites Virais (Enterovirus + Herpes Vírus 1 e 2) & 48 & 84 & 132 & NA \\
Meningites por Enterovirus, n (\%) & $35(73)$ & $71(84)$ & $106(80,3)$ & 0,107 \\
Meningites por Herpes Vírus 1 e 2, n (\%) & $13(27)$ & $13(16)$ & $26(19,7)$ & 1,0 \\
\hline Total & $\mathbf{1 2 6 4}$ & $\mathbf{1 2 7 2}$ & $\mathbf{2 5 3 6}$ & \\
\hline
\end{tabular}

NA: não aplicado. 


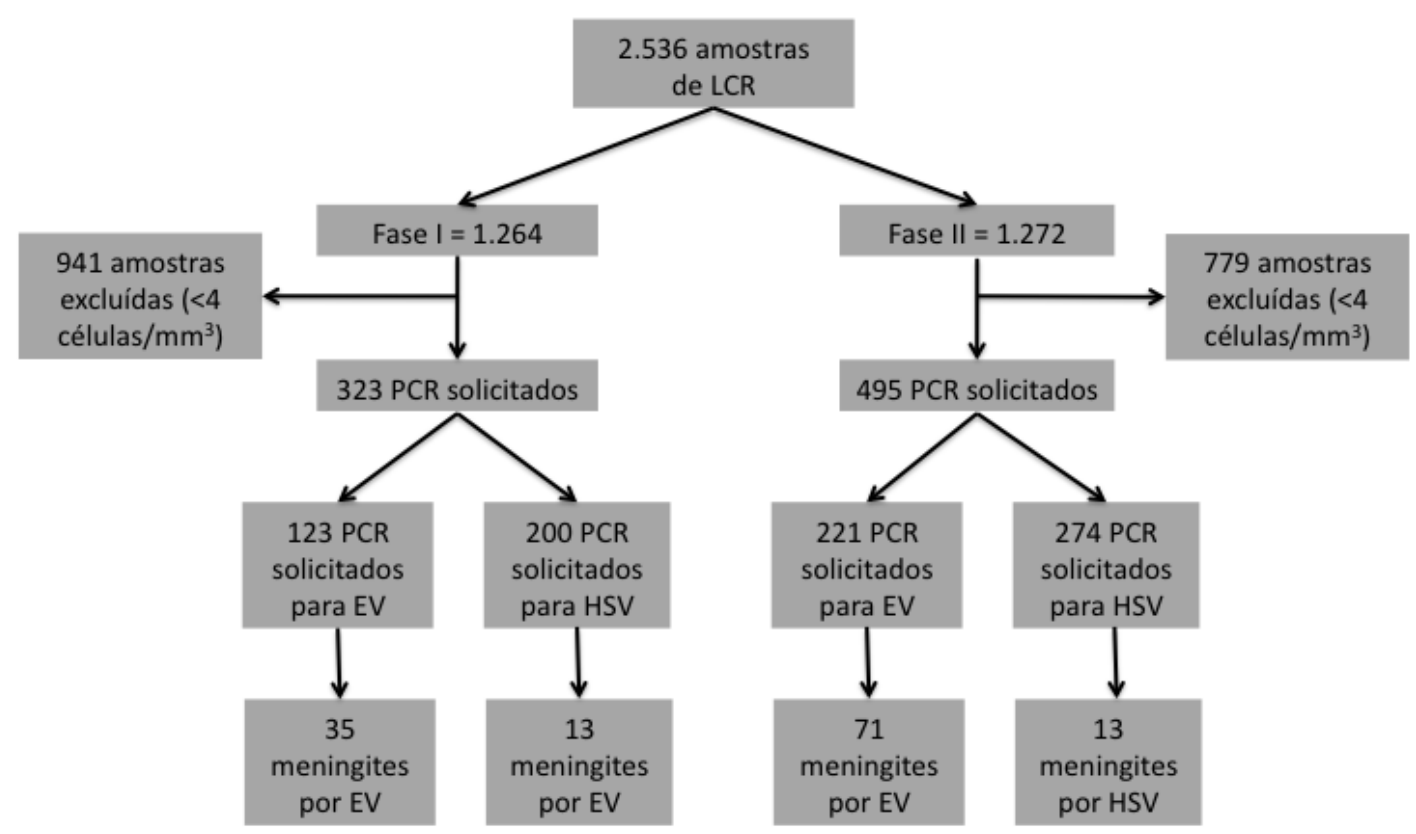

LCR: líquido cefalorraquidiano; PCR: reação em cadeia da polimerase; EV: enterovirus; HSV: herpes simples vírus.

Figura 2. Distribuição das amostras de líquido cefalorraquidiano e de solicitações de PCR conforme a fase do estudo e o agente etiológico

Dentre o grupo dos pacientes com meningite viral (tanto por enterovirus quanto por HSV - Tabela 7), $52,1 \%$ na fase I e $36,9 \%$ na fase II eram do sexo feminino $(p=0,9)$. A idade média dos envolvidos foi de 19,96 anos (desvio-padrão de 16,4) na fase I e 17,5 anos (desvio-padrão de 17,3) na fase II $(p=0,43)$. Apresentavam alguma comorbidade $23,4 \%$ na fase I e $14,3 \%$ na fase II $(p=0,19)$. A média do número de dias de internação foi de 2,9 (dp 2,6) na fase I e 2,7 (dp 3,9) na fase II $(p=0,69)$.

Dentre o grupo envolvendo as meningites virais por enterovirus e HSV (Tabela 7), os sinais e sintomas mais comumente encontrados foram: cefaléia (93,3\% na fase I e $92,6 \%$ na fase II) ( $p>0,99)$, náuseas e vômitos $(66,7 \%$ versus $70,4 \%)(p=0,66)$, febre $(77,8 \%$ versus $67,9 \%)(p=0,24)$ e rigidez de nuca $(42,2 \%$ versus $49,4 \%)(p=0,44)$.

Foram submetidos a exame de imagem $45,8 \%$ dos pacientes na fase I e $49,4 \%$ na fase II $(p=0,69)$, e $14,6 \%$ dos pacientes na fase I receberam tratamento com antibiótico, versus $22,6 \%$ na fase II $(\mathrm{p}=0,26)$ (Tabela 7$)$. Embora dentre as meningites por enterovirus, a duração do tratamento antibiótico tenha sido inferior a 24 horas em $78,3 \%$ dos casos. 
Tabela 7. Dados demográficos, clínicos e liquóricos da amostra englobando pacientes com meningite por enterovirus e herpes simples vírus

\begin{tabular}{|c|c|c|c|}
\hline Variáveis & $\begin{array}{l}\text { Fase I } \\
(n=48)\end{array}$ & $\begin{array}{l}\text { Fase II } \\
(n=84)\end{array}$ & Valor-p \\
\hline \multicolumn{4}{|l|}{ Sexo, n (\%) } \\
\hline Feminino & $25(52,1)$ & $31(36,9)$ & \multirow{2}{*}{0,09} \\
\hline Masculino & $23(47,9)$ & $53(63,1)$ & \\
\hline \multicolumn{4}{|c|}{ Internação em UTI, n (\%) } \\
\hline Não & $48(100)$ & $81(98,8)$ & \multirow[b]{2}{*}{$>0,99(\mathrm{~F})$} \\
\hline $\operatorname{Sim}$ & 0 & $1(1,2)$ & \\
\hline \multicolumn{4}{|l|}{ Meningite, $n(\%)$} \\
\hline Herpes & $13(27,1)$ & $13(15,5)$ & \multirow{2}{*}{0,10} \\
\hline Enterovirus & $35(72,9)$ & $71(84,5)$ & \\
\hline \multicolumn{4}{|c|}{ Presença de alguma comorbidade, $\mathrm{n}(\%)$} \\
\hline Não & $36(76,6)$ & $71(85,5)$ & \multirow{2}{*}{0,19} \\
\hline Sim & $11(23,4)$ & $12(14,5)$ & \\
\hline \multicolumn{4}{|l|}{ Cefaléia, n (\%) } \\
\hline Não & $3(6,7)$ & $6(7,4)$ & \multirow{2}{*}{$>0,99(\mathrm{~F})$} \\
\hline $\operatorname{Sim}$ & $42(93,3)$ & $75(92,6)$ & \\
\hline \multicolumn{4}{|c|}{ Febre $\left(\mathrm{T}>37.7^{\circ} \mathrm{C}\right), \mathrm{n}(\%)$} \\
\hline Não & $10(22,2)$ & $26(32,1)$ & \multirow{2}{*}{0,24} \\
\hline $\operatorname{Sim}$ & $35(77,8)$ & $55(67,9)$ & \\
\hline \multicolumn{4}{|l|}{ Rigidez de nuca, n (\%) } \\
\hline Não & $26(57,8)$ & $41(50,6)$ & \multirow{2}{*}{0,44} \\
\hline $\operatorname{Sim}$ & $19(42,2)$ & $40(49,4)$ & \\
\hline \multicolumn{4}{|c|}{$\begin{array}{l}\text { Predomínio da celularidade LCR primeira } \\
\text { coleta, } \mathrm{n}(\%)\end{array}$} \\
\hline Neutrofílico & $11(22,9)$ & $29(34,9)$ & \multirow{2}{*}{0,15} \\
\hline Linfomonocitário & $37(77,1)$ & $54(65,1)$ & \\
\hline \multicolumn{4}{|c|}{$\begin{array}{l}\text { Resultado do PCR para enterovirus na } \\
\text { primeira coleta, } \mathrm{n}(\%)\end{array}$} \\
\hline Negativo & $12(25)$ & $13(15,5)$ & \multirow{3}{*}{0,02} \\
\hline Positivo & $33(68,8)$ & $71(84,5)$ & \\
\hline Não solicitado & $3(6,3)$ & 0 & \\
\hline \multicolumn{4}{|c|}{$\begin{array}{l}\text { Resultado do PCR para herpes na } \\
\text { primeira coleta, } \mathrm{n}(\%)\end{array}$} \\
\hline Negativo & $29(60,4)$ & $64(76,2)$ & \multirow{4}{*}{0,18} \\
\hline Positivo HSV tipo I & $1(2,1)$ & 0 & \\
\hline Positivo HSV tipo II & $12(25)$ & $13(15,5)$ & \\
\hline Não solicitado & $6(12,5)$ & $7(8,3)$ & \\
\hline \multicolumn{4}{|c|}{$\begin{array}{l}\text { Predomínio da celularidade LCR segunda } \\
\text { coleta, } \mathrm{n}(\%)\end{array}$} \\
\hline Neutrofílico & 0 & 0 & \multirow{2}{*}{$* * *$} \\
\hline Linfomonocitário & $7(100)$ & $7(100)$ & \\
\hline \multicolumn{4}{|c|}{$\begin{array}{l}\text { Uso de antibióticos para tratamento da } \\
\text { meningite, } n(\%)\end{array}$} \\
\hline Não & $41(85,4)$ & $65(77,4)$ & \multirow{2}{*}{0,264} \\
\hline Sim & $7(14,6)$ & $19(22,6)$ & \\
\hline \multicolumn{4}{|c|}{ Realizou exame de imagem (crânio), n (\%) } \\
\hline Não & $26(54,2)$ & $42(50,6)$ & \multirow{2}{*}{0,694} \\
\hline Sim & $22(45,8)$ & $41(49,4)$ & \\
\hline
\end{tabular}

${ }^{\star * \star}$ Não foi possível realizar esse teste. (F): Teste exato de Fisher. 
Quanto às características liquóricas, na fase I, 77,1\% apresentavam predomínio linfomonocitário na primeira coleta, versus $65,1 \%$ na fase II $(p=0,15)$ conforme demonstrado na tabela 7. A contagem de leucócitos revelou mediana de 162.5 e IQR 85-350 na fase I, versus 118 e 59.5-313.5 na fase II, respectivamente $(p=0,174)$. Em cerca de $10 \%$ dos casos (envolvendo ambas as fases), o número de leucócitos no LCR na primeira coleta superou 500 células $/ \mathrm{mm}^{3}$. Os valores de glicose, proteínas e lactato no LCR foram bastante semelhantes nos dois grupos. Em nenhum deles houve detecção de bactérias pelo Gram, Látex positivo e/ou cultura positiva. Os detalhes em relação aos dados das amostras do LCR em ambas as fases podem ser observados na tabela 8. A figura 3 compara a contagem de leucócitos entre o EV e 0 HSV nas duas fases do estudo, enquanto a figura 4 faz o mesmo com o nível de proteínas no LCR.

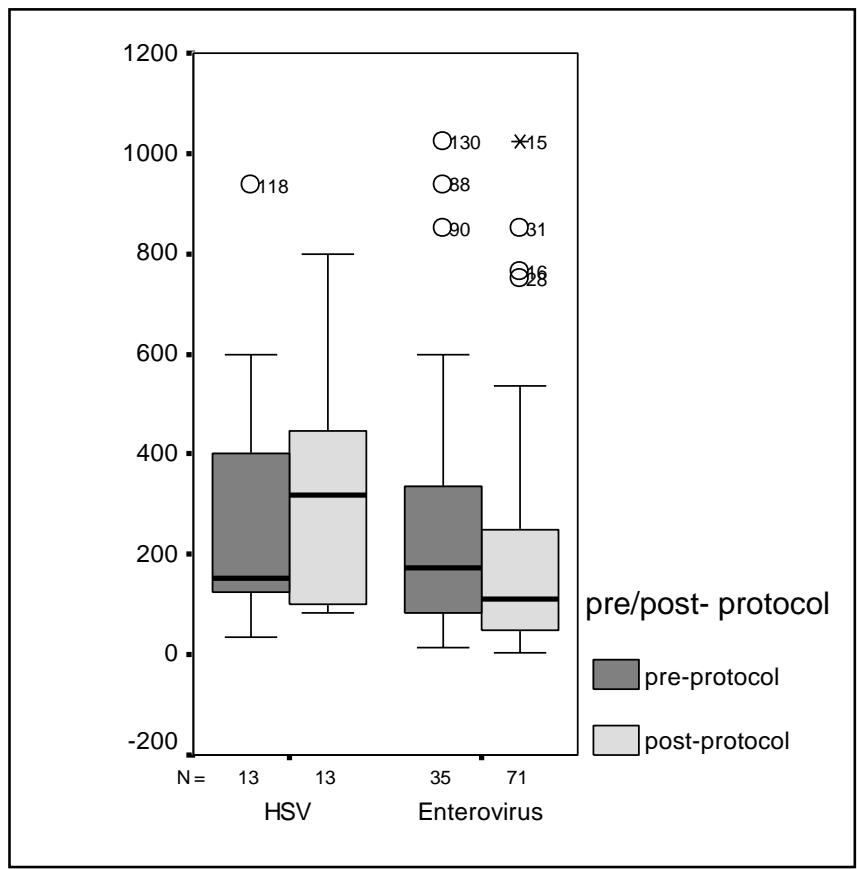

CSF WBC: contagem de leucócitos no líquor.

Pre-protocol: fase I do estudo. Post-protocol: fase II do estudo.

Figura 3. Comparativo da contagem de leucócitos no líquido cefalorraquidiano entre herpes simples vírus e enterovirus 
Tabela 8. Perfil das amostras de líquido cefalorraquidiano englobando enterovirus e herpes simples vírus

\begin{tabular}{lccc}
\hline Variáveis & $\begin{array}{c}\text { Fase I } \\
\mathbf{n}(\%)\end{array}$ & $\begin{array}{c}\text { Fase II } \\
\mathbf{n}(\%)\end{array}$ & Valor-p \\
\hline Contagem de leucócitos $\left(\mathrm{n} / \mathrm{mm}^{3}\right)$ no LCR na primeira & $262,9(259,6)$ & $205,2(217,7)$ & 0,17 \\
coleta, média (dp) & $29,9(28,5)$ & $38,3(29,2)$ & 0,11 \\
Neutrófilos no LCR na primeira coleta, média (dp) & $50,3(28,3)$ & $43,9(28,2)$ & 0,21 \\
Linfócitos no LCR na primeira coleta, média (dp) & 52,2 & 52,3 & 0,918 \\
Glicose (mg/dL) no LCR na primeira coleta, média & $50,5(34-82)$ & $41(29,2-63,5)$ & 0,035 \\
Proteína (mg/dL) no LCR na primeira coleta, mediana & $28(58,3)$ & $41(48,8)$ & 0,292 \\
(IQR) & 16,5 & 15,5 & 0,275 \\
Pandy positivo & $5,1(1,8-21,6)$ & $8,7(2,5-32,4)$ & 0,211 \\
Lactato (mg/dL) no LCR na primeira coleta, média & & & \\
Proteína C reativa (mg/L), mediana (IQR) & &
\end{tabular}

Quando analisamos apenas o subgrupo envolvendo as meningites virais por enterovirus, notamos que a média de dias de internação foi de 2,4 (dp 2,3) para fase I versus $1,9(\mathrm{dp} 2,4)$ para fase II $(p=0,25)$. A administração de antibióticos para o tratamento da meningite ocorreu em 6 casos (17,1\%) na fase I versus 18 casos $(25,4 \%)$ na fase II $(p=0,34)$. Observe a tabela 9 para os dados englobando apenas as meningites por enterovirus. O padrão linfomonocitário ao LCR foi de $71,4 \%$ na fase I e $59,2 \%$ na fase II $(p=0,21)$ e o perfil da análise do LCR pode ser observado na tabela 10.

Tabela 9. Dados demográficos e clínicos referentes às meningites por enterovirus

\begin{tabular}{lccc}
\hline Variáveis & Fase I & Fase II & Valor-p \\
\hline Idade, média (dp) & $12,5(11,7)$ & $12,4(12,7)$ & 0,989 \\
Sexo feminino, $\mathrm{n}(\%)$ & $14(40)$ & $19(26,8)$ & 0,166 \\
Tempo de sintomas até diagnóstico, média (dp) & $2,3(2,5)$ & $1,6(1,3)$ & 0,103 \\
Cefaléia, $\mathrm{n}(\%)$ & $29(90,6)$ & $63(92,6)$ & $0,708(\mathrm{~F})$ \\
Náuseas e Vômitos, $\mathrm{n}(\%)$ & $24(75)$ & $51(75)$ & $*$ \\
Febre $>37,7^{\circ} \mathrm{C}, \mathrm{n}(\%)$ & $26(81,3)$ & $50(73,5)$ & 0,399 \\
Rigidez de nuca, $\mathrm{n}(\%)$ & $13(40,6)$ & $32(47,1)$ & 0,546 \\
Fotofobia, $\mathrm{n}(\%)$ & $5(15,6)$ & $3(4,4)$ & $0,106(\mathrm{~F})$ \\
Dias de Internação, média(dp) & $2,43(2,3)$ & $1,87(2,4)$ & 0,256 \\
Exames de imagem (crânio) para diagnóstico da meningite, & $13(37,1)$ & $29(40,8)$ & 0,714 \\
$\mathrm{n}(\%)$ & $6(17,1)$ & $18(25,4)$ & 0,342 \\
Uso de antibióticos para tratamento da meningite, $\mathrm{n}(\%)$ & \multicolumn{2}{c}{. } &
\end{tabular}




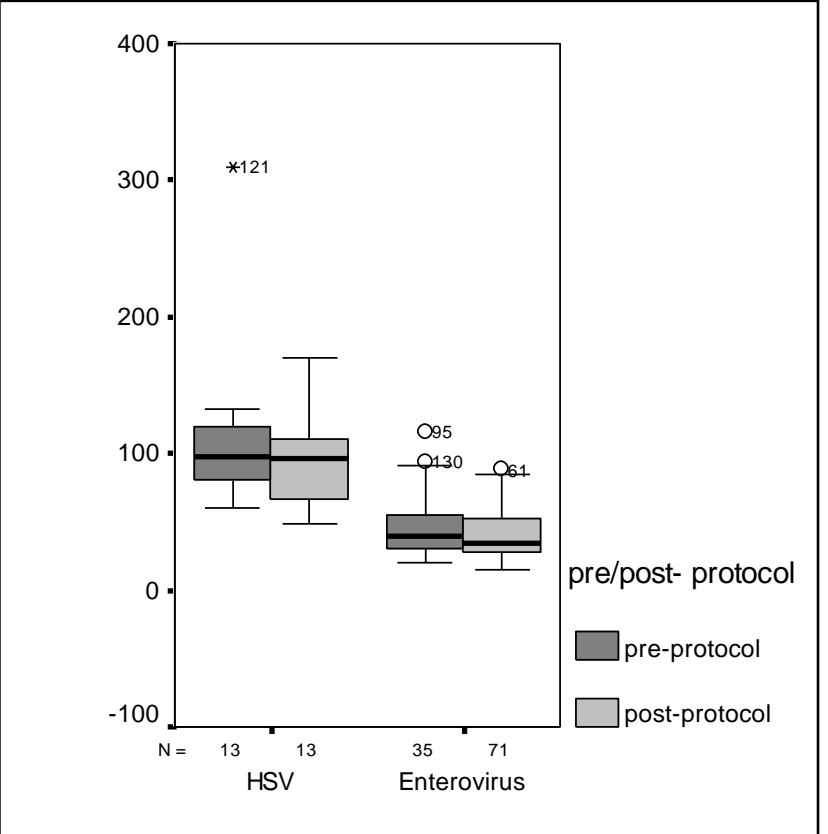

CSF protein level: nível de proteínas no líquor. Preprotocol: fase I do estudo Post-protocol: fase II do estudo.

Figura 4. Comparativo entre o nível de proteínas no líquido cefalorraquidiano nas meningites por enterovirus e herpes simples vírus

Tabela 10. Perfil das amostras de líquido cefalorraquidiano englobando as meningites por enterovirus

\begin{tabular}{lccc}
\hline Variáveis & $\begin{array}{c}\text { Fase I } \\
\mathbf{n}(\%)\end{array}$ & $\begin{array}{c}\text { Fase II } \\
\mathbf{n}(\%)\end{array}$ & Valor-p \\
\hline Contagem de leucócitos $\left(\mathrm{n} / \mathrm{mm}^{3}\right)$ no LCR na primeira & $254,9(262,5)$ & $184,5(208,5)$ & 0,13 \\
coleta, média (dp) & $38,7(27,3)$ & $43,9(27,8)$ & 0,36 \\
Neutrófilos no LCR na primeira coleta, média (dp) & $40,2(23,1)$ & $37,5(24,6)$ & 0,58 \\
Linfócitos no LCR na primeira coleta, média (dp) & 53,7 & 52,7 & 0,549 \\
Glicose (mg/dL) no LCR na primeira coleta, média & $39(30-56)$ & $35(28-53)$ & 0,17 \\
Proteína (mg/dL) no LCR na primeira coleta, mediana & $15(42,9)$ & $28(39,4)$ & 0,736 \\
(IQR) & 14,6 & 14,1 & 0,361 \\
Pandy positivo & $6,9(2,4-21,6)$ & $11,7(3,8-37)$ & 0,301 \\
Lactato (mg/dL) no LCR na primeira coleta, média & &
\end{tabular}




\section{DISCUSSÃO}

A síndrome da meningite aguda pode apresentar um curso bastante variável, a depender da etiologia. Meningite bacteriana aguda pode ser uma condição ameaçadora da vida, passível de diversas sequelas neurológicas e um grau de comprometimento significativo. Por outro lado, meningite asséptica costuma ter uma evolução benigna, favorável e auto-limitada. Desse modo, um diagnóstico rápido e acurado de meningite viral pode impactar positivamente no manejo clínico desses pacientes.

Os pequenos volumes de líquor disponíveis aliado a uma grande variedade de vírus que podem ocasionar meningite ou encefalite transformam a busca pelo diagnóstico em um grande desafio. ${ }^{(41)}$

O enterovirus representa a principal causa de meningite asséptica e responde por até $90 \%$ dos casos de infecção no SNC em que algum agente causal é identificado. ${ }^{(1,2,4)}$ As infecções variam desde quadro leves até condições ameaçadoras de vida. (4,13,14) Chang et al. observaram associação de sequela grave do neurodesenvolvimento em pacientes infectados pelo enterovirus, especificamente do sorotipo EV71, e que tiveram acometimento do SNC. ${ }^{(31)}$

Os sinais e sintomas mais comumente observados englobam cefaléia, febre, náusea, vômito e rigidez de nuca. Crise convulsiva, exantema, diarreia, são achados menos comuns. Uma série de outros estudos demonstrou quadro clínico bastante semelhante. ${ }^{(1,2,11,13,17,42)}$ Menasalvas-Ruiz et al. demonstraram em seu estudo dois picos de incidência na infância com diferentes quadros clínicos: nas crianças até os dois anos de idade, predominou um quadro febril sem foco; entre as de 3 a 7 anos de idade, os achados típicos de meningite asséptica, principalmente febre, cefaléia, vômitos e meningismo. ${ }^{(43)}$ Durante o episódio viral, foi comum observar sintomas semelhantes em outros membros da família, principalmente crianças abaixo dos 3 anos de idade. ${ }^{(43)}$

As meningites virais se comportam de maneira sazonal, predominando nas estações de outono e verão, ${ }^{(3,6,11,14,42,44)}$ fato esse que não foi observado em nenhum dos dois períodos do nosso estudo. Em países tropicais e subtropicais, ocorre uma alta incidência ao longo de todo o ano, talvez associado ao modo de transmissão fecal-oral, que pode ser facilitado durante períodos de tempo 
quente, principalmente entre as crianças. ${ }^{(45)}$ Muitos estudos demonstraram episódios epidêmicos envolvendo enterovirus, coxsackievirus, echovirus, entre outros. ${ }^{(16,17,31,46)}$ Tal fato também não foi observado em nossa amostra. Esse dado é de fundamental importância epidemiológica visto que a incidência da meningite asséptica depende mais das ocorrências epidêmicas do que das próprias tendências anuais. ${ }^{(42)}$

Como já demonstrado em diversos estudos, há uma predominância do sexo masculino. ${ }^{(13,17,43)} \mathrm{Na}$ nossa amostra, praticamente não houve diferença na distribuição entre os gêneros na primeira fase do estudo, mas na segunda fase a proporção foi de quase 2:1.

A investigação diagnóstica se inicia a partir do quadro clínico, muitas vezes é inespecífico, bem como testes laboratoriais convencionais, como hemograma e a proteína $C$ reativa. $O$ exame de LCR nem sempre auxilia a diferenciar meningite viral de bacteriana, já que em uma parcela dos casos existe predomínio polimorfonuclear na fase inicial da meningite viral, além de hiperproteinorraquia e hipoglicorraquia serem observadas numa parcela menor dos casos. ${ }^{(10,42)} \mathrm{Em}$ sua análise envolvendo mais de 500 pacientes, Michos et al. encontraram elevação de proteínas e redução da glicose no LCR em crianças abaixo de 1 ano de idade de maneira estatisticamente significativa, reforçando a possibilidade de erros nas tomadas de decisão e gerando sérias consequências aos pacientes. ${ }^{(42)}$

Diversos estudos apontam a presença de pleocitose no LCR apesar de se tratar de uma infecção viral, ${ }^{(47)}$ e quando presente, representa um indício maior de inflamação das meninges do que do parênquima cerebral. ${ }^{(26)} \mathrm{O}$ grau da presença de pleocitose varia conforme a faixa etária do indivíduo, chegando a $96 \%$ nas crianças acima de 2 anos e apenas $41 \%$ naquelas abaixo de 2 anos de idade, conforme demonstrado no estudo de Archimbaud et al. ${ }^{(47)}$ Por outro lado, Kleines et al. demonstraram não haver relação entre a concentração de proteínas no LCR e os diferentes vírus avaliados (HSV, EV, VZV, EBV) nas diferentes faixas etárias (avaliaram desde neonato até idosos), sugerindo que esse parâmetro possa ter utilidade clínica limitada. $^{(48)}$

A ausência de pleocitose parece ser comum entre as crianças abaixo dos 3 meses de idade e tem sido relacionada à idade mais jovem e à baixa contagem de leucócitos séricos. A ausência de pleocitose foi associada com uma duração menor dos sintomas na maioria dos pacientes jovens. ${ }^{(49)}$ Menasalvas-Ruiz et al. acreditam que a procura pelo pronto-socorro mais precoce nessa faixa etária 
também possa influenciar os achados do LCR. ${ }^{(43)}$ Davies et al. estudaram quais fatores poderiam influenciar na detecção de vírus em amostras de LCR de pacientes com suspeita de infecção no SNC. Foram incluídas amostras testadas para herpes vírus, JC vírus, EBV e EV. Em 53\% das amostras avaliadas no estudo de Davies et al. que tinham PCR positivo para qualquer um dos vírus relatados acima (sendo que os vírus encontrados mais frequentemente foram o EBV, EV e HSV), a celularidade no LCR foi normal; e em 34\% das amostras que foram positivas para PCR, tanto a proteinorraquia quanto a celularidade no LCR eram normais. ${ }^{(26)}$

A cultura viral foi utilizada como padrão ouro no diagnóstico de infecção por enterovirus durante muitos anos. Contudo, o longo período usualmente necessário para a positividade da amostra e a necessidade de uma equipe altamente treinada acabou limitando seu uso, visto não ser capaz de fornecer o resultado no momento em que as decisões precisam ser tomadas, influenciando no manejo desses pacientes, ${ }^{(1,42)}$ além de representar um método de alto custo e geralmente menos sensível que o método molecular. ${ }^{(50)}$

Enquanto isso, a sorologia tem papel limitado no diagnóstico das meningites virais, visto a grande diversidade de sorotipos envolvidos. ${ }^{(42)}$ É fundamental uma ferramenta que seja capaz de identificar e quantificar rapidamente os diferentes vírus nas amostras de LCR nos pacientes hospitalizados com infecção do SNC. ${ }^{(41)}$

Durante os últimos anos, as técnicas envolvendo amplificação do ácido nucleico se aperfeiçoaram significativamente, ganhando espaço e aceitação no laboratório clínico e na prática cotidiana, sendo utilizado cada dia mais, e para as mais diversas finalidades. ${ }^{(51)}$ A dificuldade em se isolar determinados agentes, bem como os altos custos de alguns dos métodos mais tradicionalmente utilizados, contribuíram para esse crescimento das técnicas biomoleculares. ${ }^{(51)}$ Inúmeros estudos já comprovaram que a sensibilidade do método é superior a de outros métodos considerados tradicionais, como a sorologia e a cultura viral, além de mais custo-efetiva. ${ }^{(15,50)}$

$\mathrm{Na}$ validação interna dos métodos de análise e detecção do enterovirus realizada em nosso serviço, comparando-se 50 amostras entre os kits Nanogen e Cepheid, a sensibilidade para este último foi melhor, sendo que em duas amostras o enterovirus foi detectado apenas pelo kit da Cepheid, enquanto em uma amostra, o enterovirus foi detectado apenas pelo Nanogen, provavelmente por ser algum dos sorotipos não detectados pelo Cepheid. 
Desde o ano de 2008, quando o uso do PCR para enterovirus começou a ser estimulado em nosso serviço, o número de casos diagnosticados aumentou progressivamente, alcançando 112 casos positivos para enterovirus dentre 242 casos suspeitos (46,3\% da amostra) no ano de 2011 . O número de diagnóstico praticamente dobrou, enquanto não foi observada tal alteração para o HSV, reforçando o benefício no uso do PCR para enterovirus como uma rotina institucional. Vale ressaltar ainda que não observamos redução no tempo de internação hospitalar nem no tempo de exposição ao tratamento antimicrobiano, visto que a amostra analisada englobou apenas pacientes com o diagnóstico confirmado de meningite viral. É possível que na fase I pacientes com meningite por enterovirus, que não tenham sido diagnosticados pelos métodos habituais até então, tenham recebido antibiótico por alguns dias, tenham sido submetidos à coleta de liquor de controle e permanecido um período desnecessariamente mais longo de internação hospitalar simplesmente pela ausência da comprovação diagnóstica de um agente viral.

Esse é um dos pontos cruciais no manejo da meningite viral sem o recurso da biologia molecular. Por mais que o quadro clínico e os achados laboratoriais possam sugerir o diagnóstico viral, sem o isolamento do agente causal, não se tem ainda a segurança de descartar infecção bacteriana, ${ }^{(15)}$ o que acaba gerando um dilema, refletido pela internação hospitalar, uso de antibiótico, realização de exames de imagem, até que de fato seja descartada infecção bacteriana e o paciente seja liberado do hospital.

Um grupo coreano analisou mais de 17.000 amostras (envolvendo swab retal ou de fezes, de orofaringe, sangue, líquor e outros fluidos como saliva, urina e líquido pericárdico) e observou ao longo de 13 anos a prevalência anual de EV através dos diferentes métodos diagnósticos. Na fase em que o método diagnóstico foi a cultura viral, foi detectado EV em $20,5 \%$ da amostra, ao passo que na segunda fase, quando utilizaram RT-PCR, $26,4 \%$ foi detectado, e na terceira fase, onde se utilizou o RT-PCR em tempo real, a positividade elevou para $39,2 \% .{ }^{(44)}$ Além do ganho em sensibilidade dos métodos diagnósticos, pode ter contribuído para esses resultados a ocorrência de quatro surtos epidêmicos de EV no período do estudo.

Em seu estudo, de Crom et al. compararam duas técnicas moleculares para o diagnóstico de infecção por enterovirus. Foram 232 amostras de LCR, avaliadas por meio do GeneXpert Enterovirus Assay (GXEA) e reversetranscriptase quantitative real-time PCR (RT-qPCR), e uma parcela menor ainda foi 
submetida à cultura viral. Comparando a cultura viral com o GXEA, a sensibilidade encontrada foi respectivamente $28,6 \%$ e $82,1 \%$, enquanto a especificidade foi $97,7 \%$ e $100 \%$, respectivamente. Avaliando as amostras que foram submetidas aos dois testes moleculares e ainda tinham material suficiente para a cultura, o enterovirus foi detectado em $8,6 \%$ das amostras pela cultura viral, em 19\% pelo GXEA e em $24,1 \%$ pelo RT-qPCR. Avaliando a amostra geral, o enterovirus foi detectado em $13,8 \%$ das amostras pelo GXEA e em 17,2\% pelo RT-qPCR. ${ }^{(52)}$

Em outro estudo observacional realizado na Suíça, Giulieri et al. demonstraram uma duração menor no uso de antibiótico no grupo cujo diagnóstico foi obtido com GeneExpert, bem como um uso significativamente menor de aciclovir e menos tempo de hospitalização. ${ }^{(53)}$

A carga viral de enterovirus nas fezes é descrita como sendo maior que no LCR durante a meningite por enterovirus, fazendo das fezes um bom material para detecção do RNA viral. ${ }^{(54)} \mathrm{Em}$ um estudo que comparou a detecção do vírus através do PCR obtido do sangue, das fezes e do líquor, alguns pontos interessantes puderam ser observados: a) a sensibilidade do PCR no LCR foi elevada nas fases iniciais da doença, demonstrando possivelmente que a deteç̧ão do RNA do enterovirus reduza com alguns dias após o início da meningite; b) o PCR no LCR detectou o RNA viral em amostras em que a cultura viral não foi capaz de isolar nenhum agente; c) o PCR realizado da amostra fecal obteve a maior sensibilidade (96\% nas fezes, $76 \%$ no LCR e nenhuma detecção viral no sangue), além de resultar positivo com maior tempo de evolução da doença. ${ }^{(54)}$ Importante salientar que a detecção do RNA do enterovirus na amostra fecal não confirma que este é o agente causal da meningite, apesar de que esse achado possa sugerir tal etiologia como altamente provável. ${ }^{(54)}$

A carga viral no LCR também parece sofrer alterações conforme o agente etiológico envolvido, tendo sido maior em pacientes com meningite por EV30 do que naqueles com meningite pelo EV6. ${ }^{(49)}$

Lévêque et al. compararam os resultados obtidos com o PCR em tempo real a uma nova tecnologia que envolve amplificação do PCR com análise de espectrometria de massa (PCR-MS). ${ }^{(41)} \mathrm{O}$ método baseado em espectrometria de massa demonstrou resultados concordantes com as técnicas habituais de PCR, alcançando um coeficiente kappa acima de 0,80 para HSV, VZV e EV, ${ }^{(41)}$ porém de apenas 0,34 para EBV. O diagnóstico de co-infecções foi superior no PCR-MS, 
identificando 26 co-infecções contra apenas 4 do método de PCR de rotina. Além disso, foi capaz de identificar uma série de vírus neurotrópicos não incluídos no painel do PCR de rotina. Contudo, o aspecto quantitativo do método PCR-MS é questionável, demonstrando uma correlação pobre entre os métodos. Desse modo, apesar do método ser capaz de identificar um número mais amplo de agentes neurotrópicos, demonstrou ter uma sensibilidade para EV e EBV abaixo daquela encontrada com PCR tradicional, além de ter um custo ainda superior nos dias atuais, limitando assim sua utilização. ${ }^{(41)}$

Sendo assim, nos dias atuais, o método tido previamente como tradicional e padrão ouro - a cultura viral - vem sendo substituída pelos testes de amplificação do ácido nucleico para detecção de enterovirus no LCR. ${ }^{(52)}$ Não há mais dúvidas quanto ao uso do PCR como novo padrão-ouro para diagnóstico de EV e HSV em infecções do SNC. ${ }^{(51)} \mathrm{O}$ GeneXpert se mostrou uma opção atrativa, mesmo para laboratórios com pouca experiência com outras técnicas diagnósticas moleculares, visto a facilidade de uso e interpretação do software. ${ }^{(30)}$ Diversos estudos tem demonstrado que o uso dos testes moleculares de rotina na suspeita clínica de meningite tem otimizado o manejo desses pacientes, através da redução da permanência hospitalar, do uso de antibióticos e custos relacionados ao hospital, diante de um quadro clínico compatível e um resultado positivo para enterovirus. ${ }^{(4,9,10,42,43,55,56)}$ Quando o diagnóstico envolve HSV-1 e 2, VZV e CMV, proporciona vantagem adicional da administração do tratamento antiviral, quando indicado, de maneira adequada diante do diagnóstico precoce. ${ }^{(56)} \mathrm{O}$ diagnóstico de meningite por EV, encefalite por HSV e infecções por CMV em pacientes imunocomprometidos são exemplos do uso clinicamente relevante e custo-efetivo dos testes moleculares. ${ }^{(50)}$ Archimbaud et al. demonstraram através de uma análise multivariada na subpopulação adulta que o tempo de resposta ao teste turnaround time (TAT), ou seja, o tempo que leva para o resultado do PCR ser liberado em relação ao momento em que a amostra deu entrada ao laboratório, foi correlacionado com o tempo de permanência hospitalar, de tal modo que cada $24 \mathrm{~h}$ de aumento no TAT esteve associado a um aumento médio de $45 \%$ no tempo de permanência hospitalar. O mesmo não foi observado na subpopulação pediátrica. ${ }^{(47)} \mathrm{O}$ impacto clínico de um resultado molecular positivo para enterovirus varia de acordo com o grupo etário dos pacientes, ${ }^{(47)}$ sendo que parece ter impacto menor no manejo dos pacientes adultos, até mesmo pela menor prevalência da doença nessa população. ${ }^{(10)}$ 
A sensibilidade do método também depende do momento da coleta da amostra e a carga viral. O intervalo entre o início dos sintomas e o momento em que se realiza a coleta da amostra de LCR é muito importante. Pacientes frequentemente buscam auxílio médico quando os sintomas já se agravaram, e talvez nesse momento o vírus não seja mais detectável no SNC, podendo contribuir para uma baixa detecção ou um teste falso negativo. ${ }^{(57)}$

Uma série de estudos já demonstrou redução no tempo de internação hospitalar bem como redução no tempo de uso de terapia antibiótica e antiviral, redução no número de tomografias de crânio, culminando na redução dos custos hospitalares. ${ }^{(4,7,9-11,55)}$ Esse menor tempo de exposição ao hospital e ao tratamento antimicrobiano gera benefícios indiretos outros, como menor risco de efeitos adversos, menor impacto na flora microbiana e menor risco de desenvolvimento de resistência antimicrobiana. ${ }^{(10,55)}$ Tais achados já eram previstos em estudos mais antigos, quando as técnicas moleculares encontravam-se ainda em desenvolvimento. ${ }^{(58)}$

Um resultado positivo no PCR para enterovirus culminou na alta imediata de $63 \%$ das crianças abaixo dos 2 anos de idade no estudo de Archimbaud et al., atingindo 95\% em 24 horas, enquanto nas crianças acima de 2 anos e nos adultos, a alta hospitalar ocorreu mais tardiamente -2 dias em média. ${ }^{(10)}$ Além disso, 0 tratamento com antibiótico e aciclovir foi interrompido em 50-60\% e 62\% dos pacientes, respectivamente, quando os médicos tinham os resultados do PCR para EV e HSV disponíveis. ${ }^{(10)}$ Comparando dados clínicos dos pacientes admitidos no final de semana e aqueles admitidos durante a semana demonstraram que o tempo de permanência foi de um dia a menos e o tempo de antibiótico também foi menor quando PCR-EV era realizado diariamente. ${ }^{(10)}$

Conforme a técnica de biologia molecular para diagnóstico de enterovirus vem se difundindo, algumas dificuldades de interpretação também podem ocorrer. O fato de o material genético viral ter sido detectado, não representa necessariamente que ele está causando os sintomas. Mesmo em situações em que a desordem do SNC esteja tipicamente associada com alguma infecção viral, a detecção de atividade viral não deve excluir outras etiologias alternativas, que podem de maneira secundária reativar o vírus então detectado. ${ }^{(48)}$ Essa interpretação pode ser ainda mais difícil em pacientes que estejam vivenciando uma doença neurológica que não é comumente associada com infecção viral. Dentre esses pacientes, o EBV parece ser o 
vírus predominante, embora outros vírus, como HSV, VZV, CMV e EV também tenham sido detectados em baixas frequências. ${ }^{(48)} \mathrm{Em}$ teoria, co-infecção bacteriana e enterovirus pode interferir com a aplicação clínica de um resultado positivo do GeneExpert, embora na prática, essa correlação não tenha sido observada. ${ }^{(53)}$

Ao lançar mão do método de PCR para diagnóstico das infecções virais, algumas implicações merecem destaque: o espectro de diferentes infecções nas diferentes faixas etárias, o quadro clínico associado a cada agente infeccioso, o impacto dos achados positivos do PCR, a utilidade de um teste ser repetido e a curva de clearance viral. ${ }^{(48)}$

Kleines et al. demonstraram em sua análise retrospectiva envolvendo mais de 3.000 pacientes que VZV, EV e HSV foram frequentemente detectados em meningite asséptica, enquanto o HSV foi a principal causa de encefalite. ${ }^{(48)}$ Observaram ainda que o VZV e HSV apresentaram clearance mais lento, sendo identificados no $12^{\circ}$ dia e $15^{\circ}$ dia, respectivamente, de tal modo que se recomenda a reavaliação de resposta ao tratamento com teste de PCR repetidos em amostras de LCR coletados mais tardiamente. ${ }^{(48)}$ Dentre os pacientes com PCR positivo no LCR e alguma condição neurológica outra, o acidente vascular encefálico foi o principal diagnóstico. ${ }^{(48)}$

Apesar de ter demonstrado uma série de benefícios no manejo da meningite viral, conforme já mencionado anteriormente, devemos utilizar o recurso da maneira mais racional possível. Pensando nisso, Wilen et al. avaliaram retrospectivamente quase 11.000 amostras de LCR com PCR com a proposta de desenvolver critérios para uso racional do NAAT para HSV-1 e 2, VZV, CMV e EV. ${ }^{(56)}$ Os critérios adotados inicialmente para HSV-1 e 2, VZV, CMV e EV incluíram: a) leucócitos $>5$ células $/ \mu \mathrm{L}$ ou proteínas $>50 \mathrm{mg} / \mathrm{dL}$, b) leucócitos no $\mathrm{LCR}>5$ células $/ \mu \mathrm{L}$ e c) leucócitos $>10$ células $/ \mu \mathrm{L}$, tanto entre os pacientes imunocompetentes quanto naqueles imunodeprimidos. ${ }^{(56)}$ Observaram, por exemplo, que não houve diferença entre os níveis de proteinorraquia nas amostras de pacientes com CMV positivo e negativo, bem como por EV, justificando não ser um parâmetro utilizado como critério de inclusão para NAAT. ${ }^{(56)}$ Após terem aplicado esses critérios em toda a amostra, foi possível concluir que se utilizando como critério de aceite para realização do NAAT a presença de mais de 10 leucócitos/-L no LCR em pacientes imunocompetentes, reduziu-se então o número de amostras de NAAT para 51\% em 2013 (período da coorte de validação dos critérios), semelhante à redução de $46 \%$ obtida em pequeno 
período de pós-implementação do protocolo. Avaliando a amostra entre 2008 a 2012, e tendo como base um valor de US\$ 64,70 por teste, o uso desses critérios teria resultado em uma economia de quase US\$ 65.000,00 no período. ${ }^{(56)}$ Esses dados, que foram obtidos de maneira retrospectiva, foram aplicados numa coorte de validação envolvendo 2.126 testes, dos quais apenas 17 testes foram positivos, e desses, 15 teriam sido identificados através dos critérios de inclusão desenvolvidos pelo estudo em questão, tendo então sido implementados na rotina do serviço. ${ }^{(56)}$ Não se deve esquecer que o estudo supracitado avaliou uma população com grande percentual da amostra sendo composta por indivíduos adultos, faixa etária essa a qual sabemos de antemão que a prevalência de EV é de fato menor quando comparada com a faixa etária pediátrica.

Davies et al. avaliaram fatores de risco que poderiam estar associados à detecção dos mais diversos vírus no LCR em pacientes com suspeita de infecção do SNC. Os pacientes foram agrupados em infecção viral do SNC provável, infecção viral do SNC possível e infecção viral do SNC improvável. Dentre aqueles agrupados como provável, $30 \%$ dos PCR foram positivos, comparados aos $5 \%$ encontrados no grupo improvável. No primeiro grupo, os principais agentes isolados foram HSV e EV, enquanto o EBV foi o mais encontrado no grupo improvável. ${ }^{(26)}$

Embora saibamos que não há terapia antiviral efetiva atualmente e que o tratamento é sintomático ${ }^{(2,4,11,14)}$ com resolução espontânea na maior parte dos casos, ${ }^{(11,14)}$ e duração habitualmente inferior a sete dias, ${ }^{(1)}$ o diagnóstico molecular da meningite por enterovirus e HSV confere uma série de benefícios: redução do uso de antibiótico e consequentemente dos riscos associados a ele, menor tempo e menor número de internação, menor número de punções liquóricas de controle, redução na angústia familiar quanto ao diagnóstico e possibilidade de uma infecção bacteriana, menores custos para o hospital e para a família. O teste molecular deve ser incluído rotineiramente na abordagem inicial dos pacientes com meningite aguda sem sinais sugestivos de infecção bacteriana, principalmente durante estações epidêmicas para EV. ${ }^{(53)}$ A experiência em manusear meningite por enterovirus e a comunicação próxima entre médicos e o laboratório na prática diária se mantém essencial para a melhora do manejo clínico do paciente. ${ }^{(47)}$

Opções de tratamento específico para meningite por EV são limitadas, sendo as únicas opções a imunoglobulina sérica e o pleconaril. O pleconaril é uma medicação que inibe a replicação viral através de um mecanismo de ligação da 
cápside, sendo capaz de atingir altas concentrações no LCR quando comparado à concentração sérica. ${ }^{(59)}$ Alguns estudos demonstraram redução na duração dos sintomas naqueles com meningite por EV. ${ }^{(59)}$ Embora a correta identificação dos EV possa não contribuir direta e significativamente no manejo do paciente, é importante para o desenvolvimento futuro de estratégias vacinais para meningite viral. ${ }^{(17)}$

Apesar de as infecções por EV apresentar curso benigno e autolimitado, acometimentos mais graves da doença podem gerar sequelas graves a longo prazo, incluindo retardo no desenvolvimento neurológico e problemas comportamentais na adolescência, após ter sido infectado pelo EV na infância, de tal modo que essas crianças com infecção em SNC pelo EV, particularmente o EV71 - comumente responsável por surtos epidêmicos - podem se beneficiar de avaliação e intervenção psiquiátrica precoce. ${ }^{(31)}$

A maior parte dos pacientes acaba recebendo ao menos uma dose de antibiótico na suspeita de meningite. Quando um resultado positivo para EV for informado, o tratamento antimicrobiano pode ser interrompido como relatado previamente em alguns estudos. ${ }^{(43)}$

Países mais desenvolvidos já contam com programas de vigilância de dados bem consolidados, e nos últimos anos, vários outros países, incluindo Brasil, Turquia, China, vem estudando e montando o seu próprio banco de dados, avaliando quais as espécies mais comumente encontradas em cada país, a distribuição sazonal, a presença de epidemias, dentre outros aspectos epidemiológicos fundamentais para o adequado entendimento da doença. ${ }^{(13,17,46,57)}$

A genotipagem direta no LCR para a rápida identificação do enterovirus é factível, e a análise do LCR durante as fases aguda e persistente da infecção pode fornecer maiores detalhes acerca da patogênese da infecção no SNC através da combinação de procedimenos rápidos para diagnóstico clínico, genotipagem direta e no futuro, detecção quantitativa dos enterovirus. ${ }^{(60)}$

As infecções reemergentes pelo EV71 têm sido motivo de preocupação para saúde pública mundial. Uma série de medicamentos para o combate a esse vírus vem sendo testados, e infelizmente ainda não há vacina disponível. ${ }^{(61)}$

A despeito de todos os testes atualmente disponíveis para investigação e diagnóstico de infecções do SNC, muitos pacientes com encefalite permanecem sem diagnóstico e novos testes diagnósticos se fazem necessários. ${ }^{(50)}$ Estudos apontam que a meningite viral ainda é sub-diagnosticada no Brasil.(17) É 
possível que com o melhor entendimento do comportamento dos diferentes microrganismos causadores de tais doenças os métodos moleculares sejam capazes de trazer informações adicionais, bem como ampliar o leque de identificação em relação ao que temos hoje em dia. Para tanto, a avaliação do impacto de custoefetividade dos métodos, envolvendo análise dos desfechos, deve ser capaz de justificar a utilização de rotina do método. 


\section{CONCLUSÕES}

1. O simples fato do número de diagnósticos de meningite por enterovirus ter aumentado quase $100 \%$ durante a implementação do protocolo nos faz crer que a estratégia de realizar o PCR para enterovirus em toda coleta de líquido cefalorraquidiano seja extremamente importante. Um número enorme de estudos publicados previamente já demonstraram as dificuldades inerentes à diferenciação entre meningite viral, que se comporta comumente de maneira benigna e muitas vezes auto-limitada, de outras etiologias, incluindo entidades com curso de doença mais grave, possibilidade de sequelas a longo prazo, podendo até mesmo culminar em óbito;

2. A técnica de biologia molecular é relativamente nova na prática clínica, e em países em desenvolvimento como é o caso do Brasil, são poucos os serviços de laboratório que dispõem tal método para uso. Desde a realização desse estudo, os benefícios obtidos foram muitos. Inicialmente, o método era realizado apenas alguns dias da semana, em horário restrito; a seguir, os horários de realização do exame foram ampliados, mas ainda não havia cobertura da realização deste exame nas 24 horas do dia, nem nos dias de final de semana; e por fim, conseguimos cobertura plena todos os horários em todos os dias da semana. Ainda mais, com o aumento da demanda pelos kits para realização do exame, o departamento comercial do hospital conseguiu negociar uma redução dos custos dos kits junto à empresa fornecedora, permitindo que um número maior de pacientes pudesse desfrutar de tal vantagem. Após a adoção dessa estratégia, a liberação do resultado em até 12 horas passou a ser um indicador de qualidade do serviço;

3. Apesar de não termos observado redução no tempo de internação hospitalar nem redução na utilização global de antibióticos, foi possível observar que o antibiótico foi suspenso na maior parte dos casos diagnosticados com PCR positivo em menos de 24 horas, reiterando um dos pontos positivos de tal método;

4. Ainda se fazem necessários estudos mais consistentes capazes de avaliar o real impacto quanto à redução no tempo de uso de antibióticos, redução na permanência hospitalar e consequentemente, redução global dos custos envolvidos. De qualquer modo, sua utilização rotineira deve ser recomendada. 


\section{REFERÊNCIAS}

1. Sawyer MH. Enterovirus infections: diagnosis and treatment. Curr Opin Pediatr. 2001;13(1):65-9.

2. Zaoutis T, Klein JD. Enterovirus infections. Pediatr Rev. 1998;19(6):183-91.

3. Tavakoli NP, Wang H, Nattanmai S, Dupuis M, Fusco H, Hull R. Detection and typing of enteroviruses from CSF specimens from patients diagnosed with meningitis/encephalitis. J Clin Virol. 2008;43(2):207-11.

4. Ramers C, Billman G, Hartin M, Ho S, Sawyer MH. Impact of a diagnostic cerebrospinal fluid enterovirus polymerase chain reaction test on patient management. JAMA.

2000;283(20):2680-5.

5. Kupila L, Vuorinen T, Vainionpaa R, Hukkanen V, Marttila RJ, Kotilainen P. Etiology of aseptic meningitis and encephalitis in an adult population. Neurology. 2006;66(1):75-80.

6. Somand D, Meurer W. Central nervous system infections. Emerg Med Clin North Am. 2009;27(1):89-100.

7. Kost CB, Rogers B, Oberste MS, Robinson C, Eaves BL, Leos K, et al. Multicenter beta trial of the GeneXpert enterovirus assay. J Clin Microbiol. 2007;45(4):1081-6.

8. Tunkel AR, Hartman BJ, Kaplan SL, Kaufman BA, Roos KL, Scheld WM, et al. Practice guidelines for the management of bacterial meningitis. Clin Infect Dis. 2004;39(9):1267-84.

9. Robinson CC, Willis M, Meagher A, Gieseker KE, Rotbart H, Glodé MP. Impact of rapid polymerase chain reaction results on management of pediatric patients with enteroviral meningitis. Pediatr Infect Dis J. 2002;21(4):283-6.

10. Archimbaud C, Chambon M, Bailly JL, Petit I, Henquell C, Mirand A, et al. Impact of rapid enterovirus molecular diagnosis on the management of infants, children, and adults with aseptic meningitis. J Med Virol. 2009;81(1):42-8.

11. Stellrecht KA, Harding I, Woron AM, Lepow ML, Venezia RA. The impact of an enteroviral RT-PCR assay on the diagnosis of aseptic meningitis and patient management. $J$ Clin Virol. 2002;25 Suppl 1:S19-26.

12. Mulford WS, Buller RS, Arens MQ, Storch GA. Correlation of cerebrospinal fluid (CSF) cell counts and elevated CSF protein levels with enterovirus reverse transcription-PCR results in pediatric and adult patients. J Clin Microbiol. 2004;42(9):4199-203.

13. Sensoy G, Sel K, Ozkaya E, Cakir B, Vidinlisan S, Doganci L. Enteroviral meningitis in children in Turkey. Cent Eur J Med. 2009;4(2):253-8.

14. Roos KL, Greenlee JE. Meningitis and encephalitis. Continuum (Minneap Minn). 2011;17(5):1010-23.

15. Lee BE, Davies HD. Aseptic meningitis. Curr Opin Infect Dis. 2007;20(3):272-7.

16. Muehlenbachs A, Bhatnagar J, Zaki SR. Tissue tropism, pathology and pathogenesis of enterovirus infection. J Pathol. 2015;235(2):217-28. 
17. Dos Santos GP, Skraba I, Oliveira D, Lima AA, de Melo MM, Kmetzsch Cl, et al. Enterovirus meningitis in Brazil, 1998-2003. J Med Virol. 2006;78(1):98-104.

18. Ihekwaba UK, Kudesia G, McKendrick MW. Clinical features of viral meningitis in adults: significant differences in cerebrospinal fluid findings among herpes simplex virus, varicella zoster virus, and enterovirus infections. Clin Infect Dis. 2008;47(6):783-9.

19. Franzen-Rohl E, Tiveljung-Lindell A, Grillner L, Aurelius E. Increased detection rate in diagnosis of herpes simplex virus type 2 meningitis by real-time PCR using cerebrospinal fluid samples. J Clin Microbiol. 2007;45(8):2516-20.

20. Graham AK, Murdoch DR. Association between cerebrospinal fluid pleocytosis and enteroviral meningitis. J Clin Microbiol. 2005;43(3):1491.

21. Leland DS, Ginocchio CC. Role of cell culture for virus detection in the age of technology. Clin Microbiol Rev. 2007;20(1):49-78.

22. Polage CR, Petti CA. Assessment of the utility of viral culture of cerebrospinal fluid. Clin Infect Dis. 2006;43(12):1578-9.

23. Yerly S, Gervaix A, Simonet V, Caflisch M, Perrin L, Wunderli W. Rapid and sensitive detection of enteroviruses in specimens from patients with aseptic meningitis. J Clin Microbiol. 1996;34(1):199-201.

24. Rotbart HA, Sawyer MH, Fast S, Lewinski C, Murphy N, Keyser EF, et al. Diagnosis of enteroviral meningitis by using PCR with a colorimetric microwell detection assay. J Clin Microbiol. 1994;32(10):2590-2.

25. Schlesinger $\mathrm{Y}$, Sawyer MH, Storch GA. Enteroviral meningitis in infancy: potential role for polymerase chain reaction in patient management. Pediatrics. 1994;94(2 Pt 1):157-62.

26. Davies NW, Brown LJ, Gonde J, Irish D, Robinson RO, Swan AV, et al. Factors influencing PCR detection of viruses in cerebrospinal fluid of patients with suspected CNS infections. J Neurol Neurosurg Psychiatry. 2005;76(1):82-7.

27. Liu Y, Duan C, Zhang C, Yang X, Zhao Y, Dong R, et al. Evaluation of a viral microarray based on simultaneous extraction and amplification of viral nucleotide acid for detecting human herpesviruses and enteroviruses. PLoS One. 2015;10(3):e0117626.

28. Lai KK, Cook L, Wendt S, Corey L, Jerome KR. Evaluation of real-time PCR versus PCR with liquid-phase hybridization for detection of enterovirus RNA in cerebrospinal fluid. J Clin Microbiol. 2003;41(7):3133-41.

29. Dierssen U, Rehren F, Henke-Gendo C, Harste G, Heim A. Rapid routine detection of enterovirus RNA in cerebrospinal fluid by a one-step real-time RT-PCR assay. J Clin Virol. 2008;42(1):58-64.

30. Marlowe EM, Novak SM, Dunn JJ, Smith A, Cumpio J, Makalintal E, et al. Performance of the GeneXpert enterovirus assay for detection of enteroviral RNA in cerebrospinal fluid. J Clin Virol. 2008;43(1):110-3.

31. Chang LY, Huang LM, Gau SS, Wu YY, Hsia SH, Fan TY, et al. Neurodevelopment and cognition in children after enterovirus 71 infection. N Engl J Med. 2007;356(12):1226-34. 
32. Tan CW, Lai JK, Sam IC, Chan YF. Recent developments in antiviral agents against enterovirus 71 infection. J Biomed Sci. 2014;21:14. Figure 1 Schematic illustration of EV-71 intracellular infection and summary of the antiviral agents; p. 5.

33. Lacroix C, Querol-Audí J, Roche M, Franco D, Froeyen M, Guerra P, et al. A novel benzonitrile analogue inhibits rhinovirus replication. J Antimicrob Chemother. 2014;69(10):272332.

34. Ginocchio CC, Zhang F, Malhotra A, Manji R, Sillekens P, Foolen H, et al. Development, technical performance, and clinical evaluation of a NucliSens basic kit application for detection of enterovirus RNA in cerebrospinal fluid. J Clin Microbiol. 2005;43(6):2616-23.

35. Verstrepen WA, Kuhn S, Kockx MM, Van De Vyvere ME, Mertens AH. Rapid detection of enterovirus RNA in cerebrospinal fluid specimens with a novel single-tube real-time reverse transcription-PCR assay. J Clin Microbiol. 2001;39(11):4093-6.

36. Nolte FS, Rogers BB, Tang YW, Oberste MS, Robinson CC, Kehl KS, et al. Evaluation of a rapid and completely automated real-time reverse transcriptase PCR assay for diagnosis of enteroviral meningitis. J Clin Microbiol. 2011;49(2):528-33.

37. Seme K, Mocilnik T, Komlos KF, Doplihar A, Persing DH, Poljak M. GeneXpert enterovirus assay: one-year experience in a routine laboratory setting and evaluation on three proficiency panels. J Clin Microbiol. 2008;46(4):1510-3.

38. Pillet S, Billaud G, Omar S, Lina B, Pozzetto B, Schuffenecker I. Multicenter evaluation of the ENTEROVIRUS R-gene real-time RT-PCR assay for the detection of enteroviruses in clinical specimens. J Clin Virol. 2010;47(1):54-9.

39. Hong J, Kim A, Hwang S, Cheon DS, Kim JH, Lee JW, et al. Comparison of the genexpert enterovirus assay (GXEA) with real-time one step RT-PCR for the detection of enteroviral RNA in the cerebrospinal fluid of patients with meningitis. Virol J. 2015;12:27.

40. Pillet S, Verhoeven PO, Epercieux A, Bourlet T, Pozzetto B. Development and validation of a laboratory-developed multiplex real-time PCR assay on the BD Max System for detection of herpes simplex virus and varicella-zoster virus DNA in various clinical specimens. J Clin Microbiol. 2015;53(6):1921-6.

41. Leveque N, Legoff J, Mengelle C, Mercier-Delarue S, N'guyen Y, Renois F, et al. Virological diagnosis of central nervous system infections by use of PCR coupled with mass spectrometry analysis of cerebrospinal fluid samples. J Clin Microbiol. 2014;52(1):212-7.

42. Michos AG, Syriopoulou VP, Hadjichristodoulou C, Daikos GL, Lagona E, Douridas P, et al. Aseptic meningitis in children: analysis of 506 cases. PLoS One. 2007;2(7):e674.

43. Menasalvas-Ruiz Al, Salvador-Garcia C, Moreno-Docon A, Alfayate-Miguelez S, Perez Canovas C, Sanchez-Solis M. Enterovirus reverse transcriptase polymerase chain reaction assay in cerebrospinal fluid: an essential tool in meningitis management in childhood. Enferm Infecc Microbiol Clin. 2013;31(2):71-5.

44. Hyeon JY, Hwang S, Kim H, Song J, Ahn J, Kang B, et al. Accuracy of diagnostic methods and surveillance sensitivity for human enterovirus, South Korea, 1999-2011. Emerg Infect Dis. 2013;19(8):1268-75.

45. Vidal LR, Almeida SM, Messias-Reason IJ, Nogueira MB, Debur MoC, Pessa LF, et al. Enterovirus and herpesviridae family as etiologic agents of lymphomonocytary meningitis, Southern Brazil. Arq Neuropsiquiatr. 2011;69(3):475-81. 
46. Tao Z, Wang H, Li Y, Liu G, Xu A, Lin X, et al. Molecular epidemiology of human enterovirus associated with aseptic meningitis in Shandong Province, China, 2006-2012. PLoS One. 2014;9(2):e89766.

47. Archimbaud C, Ouchchane L, Mirand A, Chambon M, Demeocq F, Labbe A, et al. Improvement of the management of infants, children and adults with a molecular diagnosis of Enterovirus meningitis during two observational study periods. PLoS One. 2013;8(7):e68571.

48. Kleines M, Scheithauer S, Schiefer J, Hausler M. Clinical application of viral cerebrospinal fluid PCR testing for diagnosis of central nervous system disorders: a retrospective 11-year experience. Diagn Microbiol Infect Dis. 2014;80(3):207-15.

49. Volle R, Bailly JL, Mirand A, Pereira B, Marque-Juillet S, Chambon M, et al. Variations in cerebrospinal fluid viral loads among enterovirus genotypes in patients hospitalized with laboratory-confirmed meningitis due to enterovirus. J Infect Dis. 2014;210(4):576-84 .

50. Caliendo AM, Gilbert DN, Ginocchio CC, Hanson KE, May L, Quinn TC, et al. Better tests, better care: improved diagnostics for infectious diseases. Clin Infect Dis. 2013;57 Suppl 3:S139-70.

51. Huang C, Morse D, Slater B, Anand M, Tobin E, Smith P, et al. Multiple-year experience in the diagnosis of viral central nervous system infections with a panel of polymerase chain reaction assays for detection of 11 viruses. Clin Infect Dis. 2004;39(5):630-5.

52. de Crom SC, Obihara CC, van Loon AM, Argilagos-Alvarez AA, Peeters MF, van Furth AM, et al. Detection of enterovirus RNA in cerebrospinal fluid: comparison of two molecular assays. J Virol Methods. 2012;179(1):104-7.

53. Giulieri SG, Chapuis-Taillard C, Manuel O, Hugli O, Pinget C, Wasserfallen JB, et al. Rapid detection of enterovirus in cerebrospinal fluid by a fully-automated PCR assay is associated with improved management of aseptic meningitis in adult patients. J Clin Virol. 2015;62:58-62.

54. Kupila L, Vuorinen T, Vainionpäā R, Marttila RJ, Kotilainen P. Diagnosis of enteroviral meningitis by use of polymerase chain reaction of cerebrospinal fluid, stool, and serum specimens. Clin Infect Dis. 2005;40(7):982-7.

55. Huizing KM, Swanink CM, Landstra AM, van Zwet AA, van Setten PA. Rapid enterovirus molecular testing in cerebrospinal fluid reduces length of hospitalization and duration of antibiotic therapy in children with aseptic meningitis. Pediatr Infect Dis J. 2011;30(12):1107-9.

56. Wilen CB, Monaco CL, Hoppe-Bauer J, Jackups R, Bucelli RC, Burnham CA. Criteria for reducing unnecessary testing for herpes simplex virus, varicella-zoster virus, cytomegalovirus, and enterovirus in cerebrospinal fluid samples from adults. J Clin Microbiol. 2015;53(3):887-95.

57. Bastos MS, Lessa N, Naveca FG, Monte RL, Braga WS, Figueiredo LT, et al. Detection of Herpesvirus, Enterovirus, and Arbovirus infection in patients with suspected central nervous system viral infection in the Western Brazilian Amazon. J Med Virol. 2014;86(9):1522-7.

58. Smalling TW, Sefers SE, Li H, Tang YW. Molecular approaches to detecting herpes simplex virus and enteroviruses in the central nervous system. J Clin Microbiol. 2002;40(7):2317-22.

59. Desmond RA, Accortt NA, Talley L, Villano SA, Soong SJ, Whitley RJ. Enteroviral meningitis: natural history and outcome of pleconaril therapy. Antimicrob Agents Chemother. 2006;50(7):2409-14. 
60. Mirand A, Henquell C, Archimbaud C, Chambon M, Charbonne F, Peigue-Lafeuille H, et al. Prospective identification of enteroviruses involved in meningitis in 2006 through direct genotyping in cerebrospinal fluid. J Clin Microbiol. 2008;46(1):87-96.

61. Kuo RL, Shih SR. Strategies to develop antivirals against enterovirus 71. Virol J. 2013;10:28. 


\begin{abstract}
Introduction: Enterovirus and Herpes simplex viruses are common causes of lymphocytic meningitis. Purpose: To analyse the impact of the use molecular testing for Enteroviruses and Herpes simplex viruses I and II in all suspected cases of viral meningitis. Methods: From November 18, 2008 to November 17, 2009, all patients admitted with suspected viral meningitis (with pleocytosis) had a cerebrospinal fluid sample tested using a nucleic acid amplification test. Data were collected during this period - called as phase II (intervention) - and from November 18, 2007 to November 17, 2008 - called as phase I (observational), when such tests were available but not routinely used. Results: In total, 2,536 CSF samples were assessed, of which 1,264 were from phase I, and 1,272 from phase II. Of this total, a nucleic acid amplification test for Enterovirus was ordered in 123 cases during phase I (9.7\% of the total phase I sample) and in 221 cases in phase II (17.4\% of the total phase II sample). From these, Enterovirus was confirmed in $35(28.5 \%, 35 / 123)$ patients during phase I and 71 (32.1\%, 71/221) patients during phase $\mathrm{II}(\mathrm{p}=0.107)$. The rate of diagnosis of meningitis by HSV I and II did not differ between the groups (13 patients, 6.5\% in phase I and 13, $4.7 \%$ in phase II) $(p=1.0)$, from 200 cases in phase I and 274 cases in phase II. Conclusions: The number of cases diagnosed with enteroviral meningitis increased during the course of this study, leading us to believe that the strategy of performing NAAT for Enterovirus on every CSF sample with pleocytosis is fully justified.
\end{abstract}




\section{Apêndice}

Apêndice 1. Ficha de Coleta de Dados

\section{FORMULÁRIO MENINGITES VIRAIS - BIOLOGIA MOLECULAR \\ FICHA NÚMERO:}

Nome:

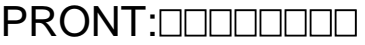

Nascimento: $\square \square / \square \square / \square \square$
Sexo: $\square \mathrm{M} \quad \square \mathrm{F}$

Idade: $\square \square$ anos

Data de internação hospitalar: $\square \square / \square \square / \square \square$

Tempo dos sintomas até a internação: $\square \square \square$ dias

Local da internação: UTI $\quad \square \mathrm{S} \quad \square \mathrm{N}$

Doença de Base (classificação pelo CID):

Número de comorbidades:
$\square$ Doença cardíaca
$\square$ Colagenose
$\square \mathrm{DPOC}$
$\square \mathrm{HIV}$
$\square$ Diabetes mellitus
$\square$ Infecção de outro local $\square$ Neoplasias
$\square$ Etilismo
$\square$ Hepatopatia
$\square$ Doença neurológica
$\square$ Insuficiência renal
$\square$ Outros

$\square \mathrm{HD} \quad \square \mathrm{DPI} \quad \square \mathrm{Nada}$

Sinais e sintomas:

$\begin{array}{llll}\text {-cefaleia } & \square S & \square \mathrm{N} & \\ \text {-nauseas ou vomitos } & \square \mathrm{S} & \square \mathrm{N} \\ \text {-febre }\left(\geq 37.8^{\circ} \mathrm{C}\right) & \square \mathrm{S} & \square \mathrm{N} & \\ \text {-rigidez de nuca } & \square \mathrm{S} & \square \mathrm{N} & \\ \text {-rash cutaneo } & & \square \mathrm{S} & \square \mathrm{N} \\ \text {-fotofobia } & \square \mathrm{S} & \square \mathrm{N} & \end{array}$

Uso de corticosteroides $\quad \square \mathrm{S} \quad \square \mathrm{N}$

Uso de imunossupressores $\quad \square S \quad \square N$

Uso de antimicrobianos $\quad \square \mathrm{S} \quad \square \mathrm{N}$ (previamente aos sintomas da meningite) 
Exames laboratoriais na admissão hospitalar:

$\mathrm{Hb} \_\mathrm{g} / \mathrm{dL} \quad \mathrm{Ht} \_$\% Leucócitos: ___ $/ \mathrm{mm}^{3}$ (neutrof $<500 \square \mathrm{S} \square \mathrm{N}$ )

plaquetas: $\quad / \mathrm{mm}^{3}$

$\mathrm{Na}: \_\mathrm{mE} / \mathrm{L} \quad \mathrm{K}: \_\mathrm{mE} / \mathrm{L}$ creat:__ $\mathrm{mg} \%$ ureia:__ $\mathrm{mg} \%$

Glicemia:___ mg\% Fosfatase alcalina:__ U/L

Proteína $\mathrm{C}$ reativa:__ $\mathrm{mg} / \mathrm{L}$

Exames laboratoriais do liquor:

\begin{tabular}{|l|l|l|}
\hline & PRIMEIRA COLETA & SEGUNDA COLETA \\
\hline № leucócitos $/ \mathrm{mm}^{3}$ & & \\
\hline \%lineutrófilos & & \\
\hline$\%$ monócitos & & \\
\hline Proteína $(\mathrm{mg} / \mathrm{dL})$ & & \\
\hline Glicose $(\mathrm{mg} / \mathrm{dL})$ & & \\
\hline Lactato $(\mathrm{mg} / \mathrm{dL})$ & & \\
\hline GRAM & & \\
\hline Látex * & & \\
\hline Culturas para bactérias & & \\
\hline Enterovirus ** & & \\
\hline Herpes vírus I e II *** & & \\
\hline Complicações & & \\
\hline Cefaléia pós-punção & & \\
\hline
\end{tabular}

* Látex para Streptococcus pneumoniae/ Haemophylus influenzae/ N. meningitidis

** Detecção de enterovirus por NAT

*** Detecção de Herpes vírus I e II por NAT

Numero de punções

Uso de antibióticos para o tratamento da meningite $\square \mathrm{S} \quad \square \mathrm{N}$

Tempo de uso de antibióticos $\square \square$ (dias)

Exames de imagem - tomo ou RNM (para diagnostico na internação ou durante a internação) $\square S \quad \square N$

Quantos exames de imagem $\square$

Data da alta/óbito: 